\title{
Persistent Scatterers Interferometry detects and measures ground subsidence in Lisbon
}

\author{
Sandra I.N. Heleno a,*, Luís G.S. Oliveira ${ }^{\text {a,b }}{ }^{\text {, Maria J. Henriques }}{ }^{c}$, Ana P. Falcão a , José N.P. Lima ${ }^{\text {c }}$, \\ Geraint Cooksley ${ }^{\mathrm{d}}$, Alessandro Ferretti ${ }^{\mathrm{e}}$, Ana M. Fonseca ${ }^{\mathrm{c}}$, João P. Lobo-Ferreira ${ }^{\mathrm{b}}$, João F.B.D. Fonseca ${ }^{\mathrm{a}}$ \\ a Instituto Superior Técnico, Instituto de Engenharia de Estruturas Território e Construção (ICIST), Av. Rovisco Pais, 1049-001 Lisboa, Portugal \\ b Laboratório Nacional de Engenharia Civil, Dep. Hidraulica e Ambiente, Av. Brasil 101, 1700-066 Lisboa, Portugal \\ c Laboratório Nacional de Engenharia Civil, Dep. Barragens de Betão, Av. Brasil 101, 1700-066 Lisboa, Portugal \\ ' Altamira-Information, C/Corsega, 381, Barcelona 08037, Spain \\ e Tele-Rilevamento Europa - TRE, Via Vittoria Colonna, 7, 20149 Milano, Italy
}

\section{A R T I C L E I N F O}

\section{Article history:}

Received 4 June 2010

Received in revised form 4 April 2011

Accepted 10 April 2011

Available online $\mathrm{xxxx}$

\section{Keywords:}

PSI interferometry

Metropolitan Lisbon

Surface subsidence

Groundwater

Leveling

GPS

\begin{abstract}
A B S T R A C T
Results from the application of Persistent Scatterers Interferometry in Lisbon Metropolitan Area revealed two previously unknown subsiding urban areas: one (Laranjeiras) is located in the center of Lisbon; another (Vialonga) is to be found toward the North, in an industrial region crossed by Lisbon's main highway and railway lines. The two subsiding sectors are bordered by sharp velocity gradients, and the subsidence pattern appears partially delimited by mapped geologic faults. Surface geology and urbanization alone are unable to explain the phenomena. In the Vialonga area, the historical record of water pore pressure shows a clear decline of the levels (up to $65 \mathrm{~m}$ in 27 years), providing evidence of over-exploitation of groundwater resources. Limited information from wells drilled inside and outside the subsidence area points to a spatial correlation between the subsidence and the water pressure levels, and suggests that faults could be acting as hydraulic barriers in the aquifer system. The surface subsidence detected is probably caused by compaction of a clay-rich Oligocene-aged aquitard, led by over-exploitation of adjacent aquifers. The same Oligocene aquitard layer is present in the Laranjeiras area, immediately bellow a multi-layered sand-clay-limestone Miocene aquifer, but further work is needed to diagnose the possibility of over-exploitation of groundwater here. In this work we were able to independently confirm the PSI results, by comparing autonomous PSI results processed for the same geographical areas, and by comparing PSI with leveling and continuous GPS derived subsidence velocities, whose close match provided further ground validation of the space-borne PSI technique.
\end{abstract}

(C) 2011 Elsevier Inc. All rights reserved.

\section{Introduction}

The Lisbon Metropolitan Area is characterized by high urban density and favorable conditions for anthropogenic ground deformations. It encloses more than 2.8 million inhabitants in an area of $\sim 300 \mathrm{~km}^{2}$, comprising two sub-regions separated by the Tagus River: to the North, Greater Lisbon, with around 2 million inhabitants, and 9 municipalities (including the city of Lisbon); to the South, the Setúbal Peninsula, with $\sim 800.000$ inhabitants. Population is concentrated mainly around the city of Lisbon (Fig. 1A), and then extends out along

\footnotetext{
* Corresponding author. Tel.: + 351 218418350; fax: + 351218419765. E-mail addresses: sandra.heleno@ist.utl.pt (S.I.N. Heleno), loliveira@lnec.pt (L.G.S. Oliveira), mjoao@lnec.pt (M.J. Henriques), apfalcao@civil.ist.utl.pt (A.P. Falcão), jnplima@lnec.pt (J.N.P. Lima), geraint.cooksley@altamira-information.com (G. Cooksley), alessandro.ferretti@treuropa.com (A. Ferretti), anafonseca@lnec.pt (A.M. Fonseca), lferreira@lnec.pt (J.P. Lobo-Ferreira), jfonseca@ist.utl.pt (J.F.B.D. Fonseca).
}

main roadways and railways (by the municipalities of Cascais, Oeiras, Amadora, and Vila Franca de Xira). In the last 40 years several political, socio-economic and cultural changes resulted in intense and rapid growth affecting the entire Metropolitan Area. Based on urban growth modeling, Silva \& Clarke (2002) predict that the south margin of the Tagus River will continue to sustain intense urban pressures, due to flatter land and to newly built transportation infrastructure. These findings point to an increasing vulnerability of the region to anthropogenic ground deformations, such as urban subsidence related to increasing urbanization load over soft soils, or subsidence related to groundwater withdrawal. In addition, the Lisbon metropolitan area is also subject to seismotectonic activity: it is located within the region where the Tagus River approaches the ocean - the Lower Tagus Basin (LTB), a tectonic depression filled with up to $2000 \mathrm{~m}$ of accumulated Cenozoic sediments, consisting mainly of interbedded clays, silts, sands, and limestones (Carvalho et al., 2005; Vis et al., 2008). In Fig. 1B the simplified geological setting of the area is shown. This region experienced very destructive earthquakes (Magnitudes 6 to 7 ) caused by the rupture of local faults, in 1344(?), 1531, 1858 and 1909 
(Vilanova \& Fonseca, 2004). The location and seismogenic potential of the local earthquakes sources are still poorly known (Carvalho et al., 2006, 2008; Oliveira, 2008; Vilanova et al., 2003).

Space-borne Synthetic Aperture Radar (SAR) imagery applications to environmental monitoring include vegetation mapping, hydrology, sea-ice mapping and geology (Oliver \& Quegan, 2004). The ability of SAR to make use of the phase in the microwave signal allowed the development of new techniques that monitor surface deformation (Burgmann et al., 2000; Hanssen, 2001; Massonnet \& Feigl, 1998). SAR interferometry (InSAR), and advanced InSAR techniques such as Persistent Scatterers Interferometry (PSI), involve interferometric phase comparison of SAR images collected at different times, and allow large-coverage measure of surface deformation with millimeter accuracy at high spatial resolutions. These techniques are especially effective in urban settings, which appear as high-coherence areas in SAR images, and hence their use in the mitigation of urban geohazards is rising. PSI (and InSAR) application to the study of urban subsidence related to groundwater withdrawal is already a proven concept, and examples include the cities of Las Vegas, Los Angeles, Granada, Mexico City, Venice, Campania, Umbria, Bologna, and Seattle (Amelung et al., 1999; Bawden et al., 2001; Cabral-Cano et al., 2008; Fernandez et al., 2009; Finnegan et al., 2008; Hoffmann et al., 2001; López-Quiroz et al., 2009; Stramondo et al., 2007; Tosi et al., 2002, 2009). In urban areas, land subsidence increases the risk of flooding, and the loss of height gradient in pipes enforces the need for water sewage repairs. Also, in areas of differential subsidence damages to housing and urban infrastructure may occur.

In this paper we report results from the first application of Persistent Scatterers Interferometry in the Lisbon Metropolitan Area. The work was done within the scope of the Global Monitoring for the Environment and Security (GMES) Terrafirma Project (www.terrafirma.eu.com). It is worth stressing that no previous information on subsidence affecting the area was known before the Terrafirma PSI results. Here we focus on the results obtained for the Northern area of metropolitan Lisbon, where this investigation has revealed significant rates of ground subsidence.

\section{Data acquisition and processing}

\subsection{InSAR and PSI overview}

The use of spaceborne SAR imagery to detect sub-centimeter nearvertical displacements of the Earth's surface started in the late 1980's (Gabriel et al., 1989). The technique, denominated SAR interferometry (InSAR), computes the interference pattern caused by the phase difference between two SAR images acquired at different times with similar viewing angles (Burgmann et al., 2000; Massonnet \& Feigl,

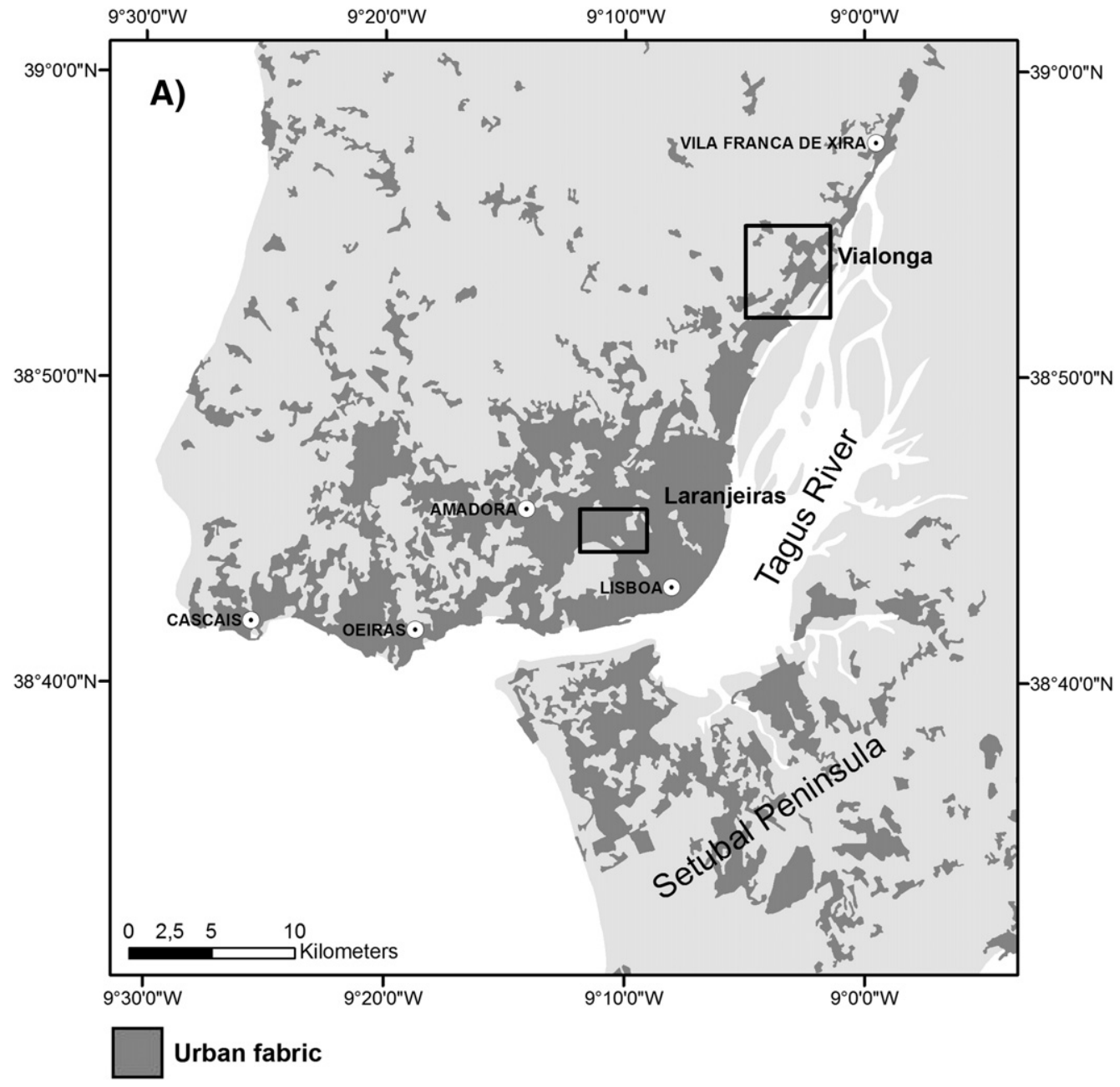

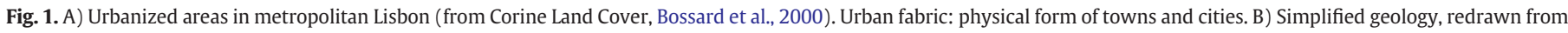

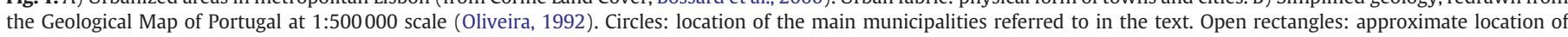
Laranjeiras and Vialonga areas, referred to later in the text. 


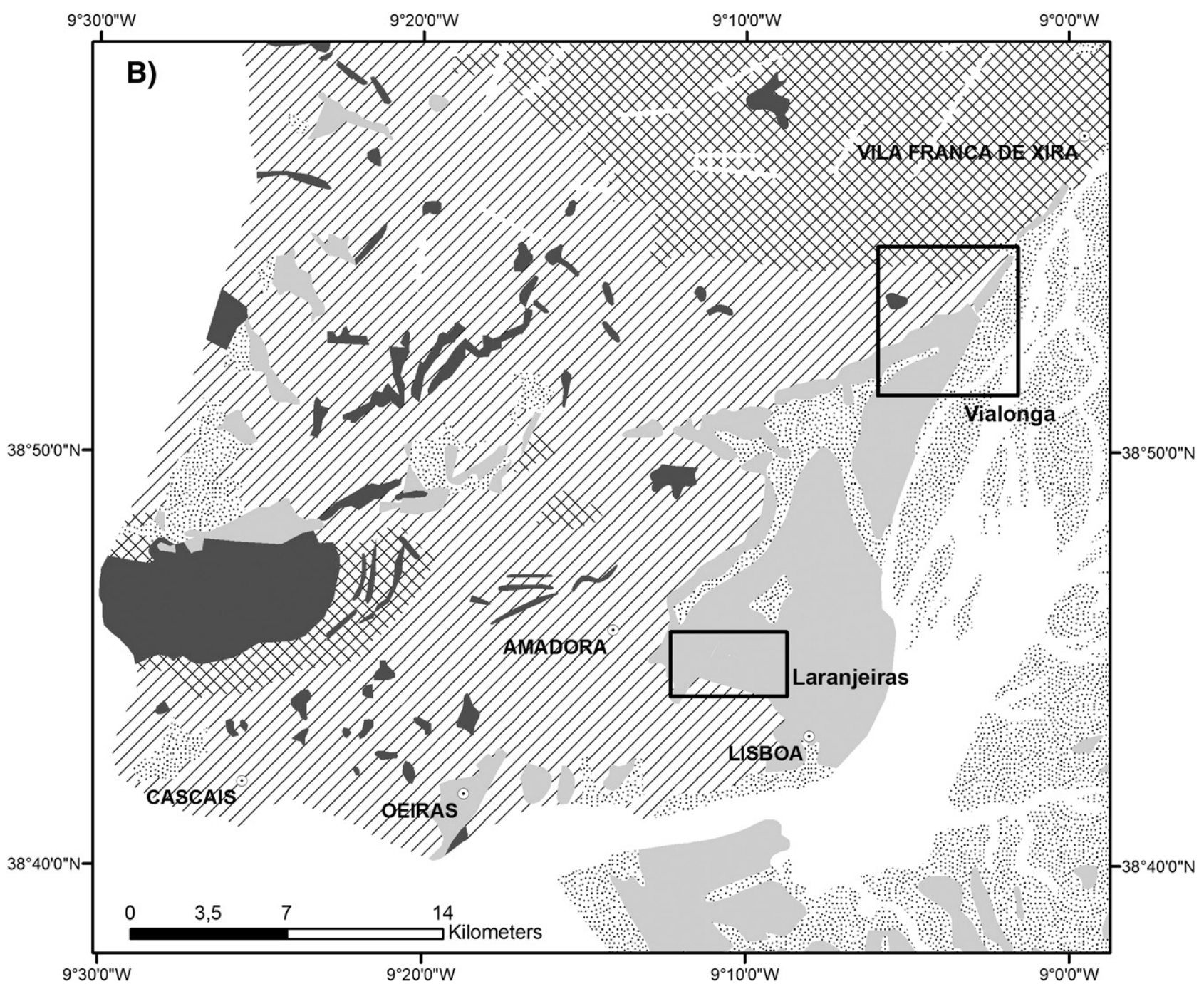

\section{Quaternary sands}

Neogene/Paleogene sands, limestones and clays

$1 / / /$, Cretaceous consolidated sands, limestones and clays

Jurassic consolidated sands, limestones and clays

\section{Volcanics/Plutonics}

Fig. 1 (continued).

1998). After correction for topographic and orbital contributions, and assuming that atmospheric effects are negligible, the resulting interferogram (with dimensions of hundreds of square kilometers) maps any deformation of the crust between the two acquisitions (e.g. 35 days orbital cycle for ERS and ENVISAT satellites). The most significant limitations of conventional InSAR (Burgmann et al., 2000; Massonnet \& Feigl, 1998) are: spatial decorrelation (due to variations in imaging geometry); temporal decorrelation (resulting from the change with time of scattering properties of the surface due to vegetation, weathering and water or snow coverage); and atmospheric effects (delays in phase propagation due to atmospheric conditions). Conventional InSAR studies achieve better results on areas that are either sparsely vegetated and dry or urbanized (where buildings contribute to stable scattering), thus minimizing image decorrelation, and on flat areas where topography-dependent atmospheric effects are smaller (Delacourt et al., 1998).

To address the problems of decorrelation and atmospheric delay, the InSAR approach to measuring ground deformation evolved toward the joint exploitation of large groups of SAR images, allowing the estimation and removal of the atmospheric phase contribution. This procedure, first developed by Ferretti et al. (2000, 2001), and generally referred to as "Persistent Scatterers Interferometry" (PSI), allows the detection of sub-millimetric movements of the ground at locations characterized by stability of the radar backscattering, and 

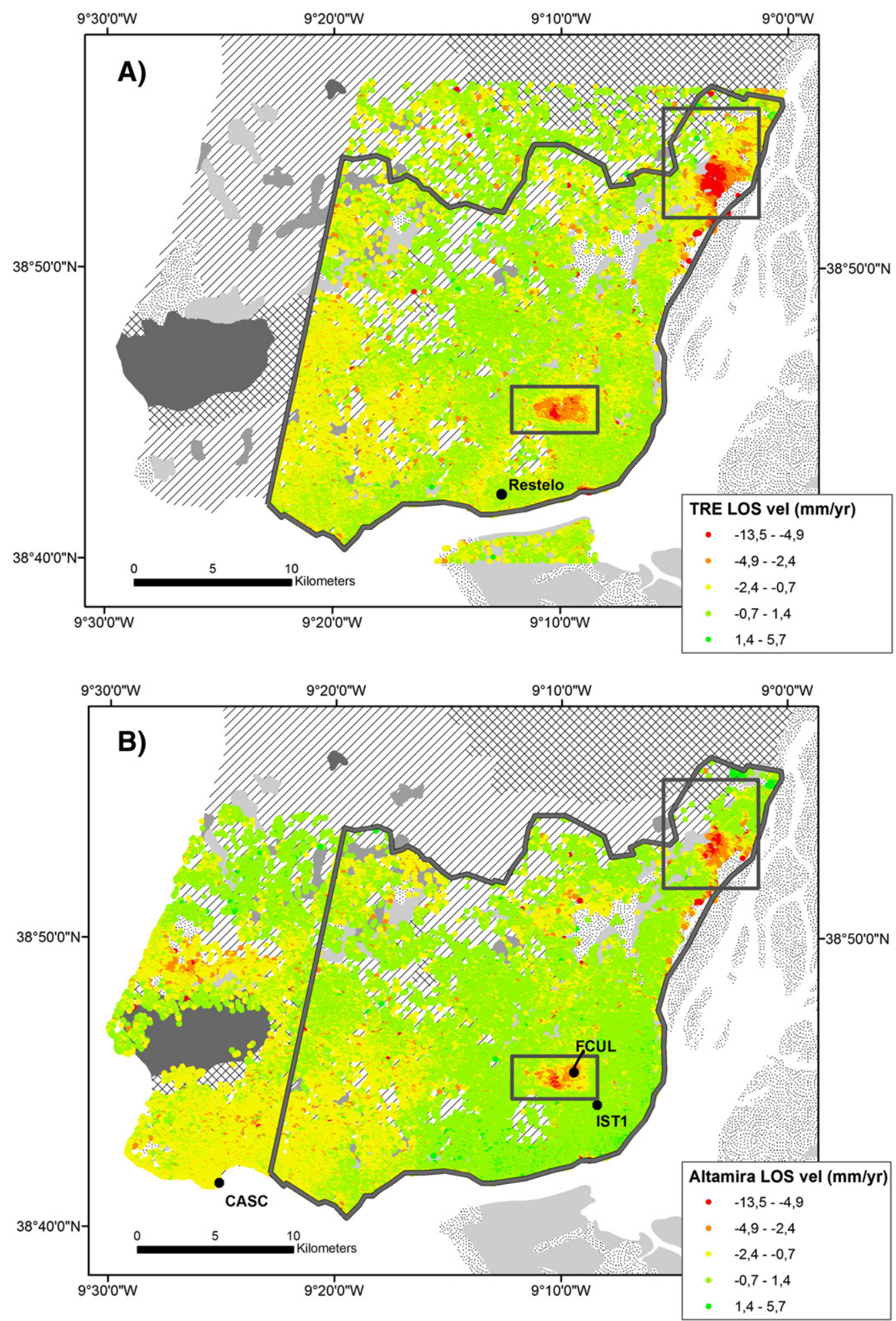

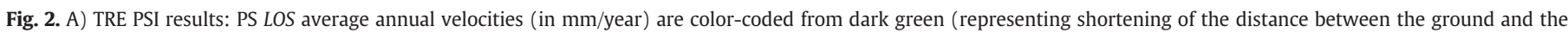

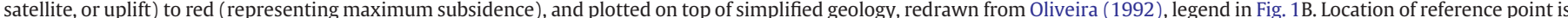

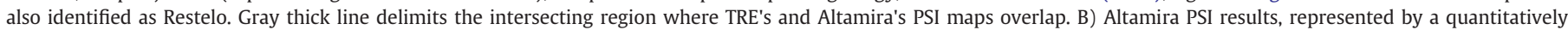

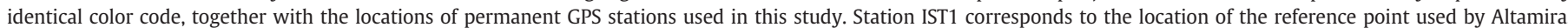

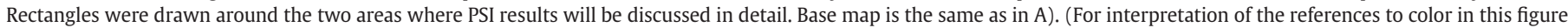
legend, the reader is referred to the web version of this article.)

hence referred to as "Persistent Scatterers" (PS). Physically these locations correspond to stable natural or man-made reflectors (like the corner of a building, or a large rock). In the SAR image, at these pixels, one scatterer may dominate the echo, behaving somewhat as point scatterer, so that decorrelation is greatly reduced (Ferretti et al., 2000, 2001). Not all PSs exhibit point like scattering mechanisms, 


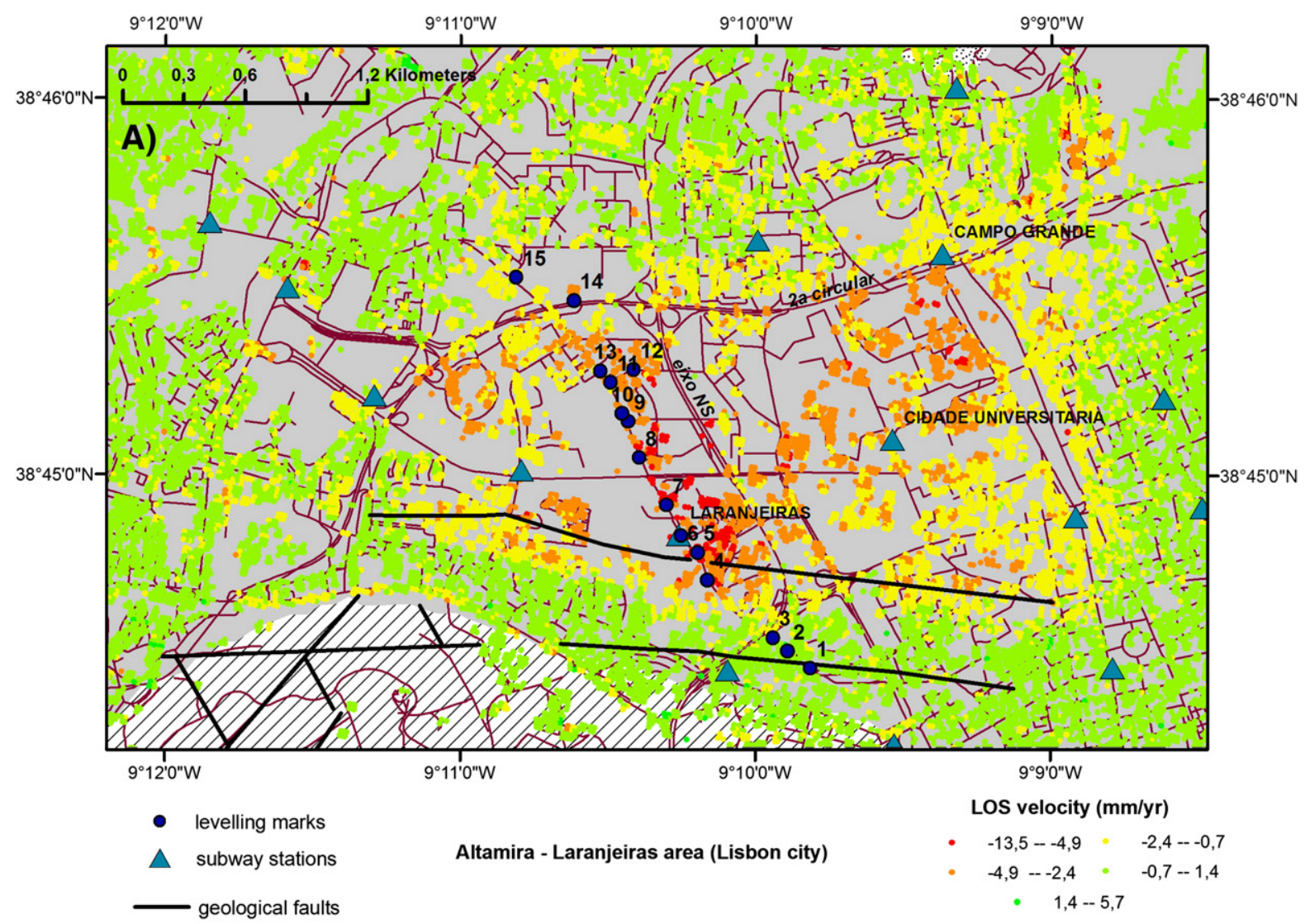

B)

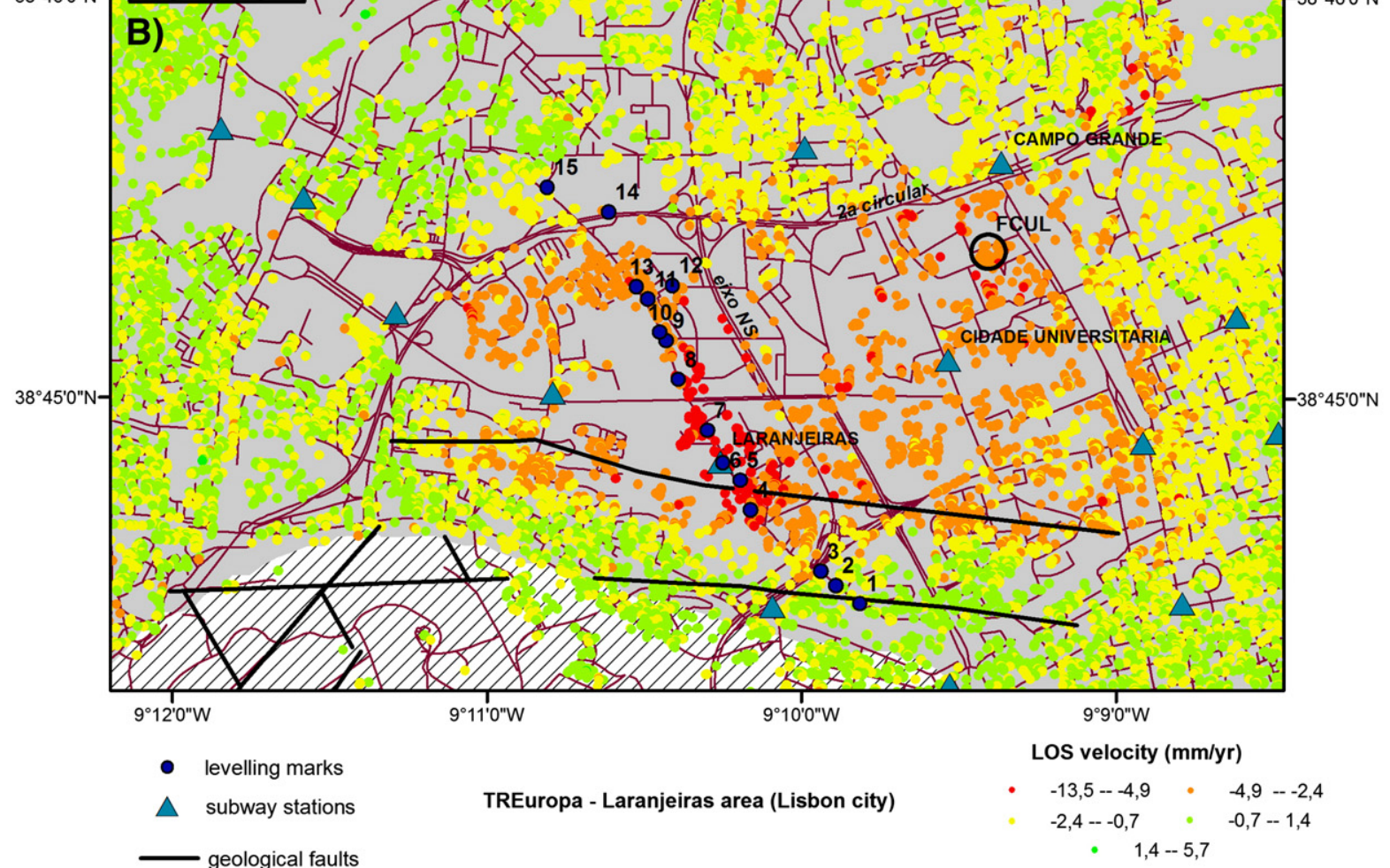




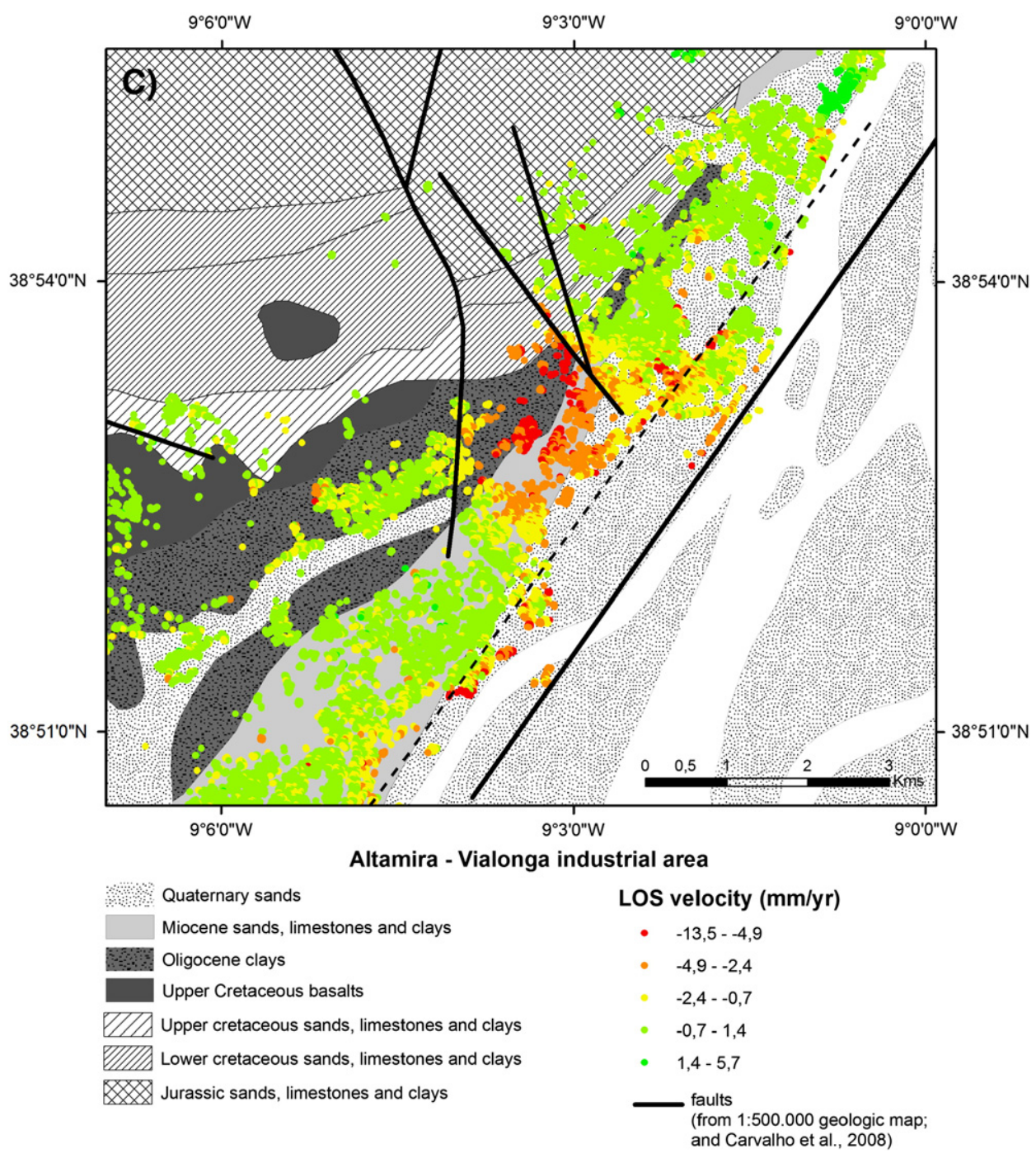

Fig. 3 (continued).

many are instead distributed phase-stable targets (Hooper et al., 2004). In the PSI approach, the interferometric phase is modeled as given by (see for example Kampes, 2006)

$\phi^{k}=\phi_{\text {topo }}^{k}+\phi_{\text {defo }}^{k}+\phi_{\text {atmo }}^{k}+\phi_{\text {noise }}^{k}$,

corresponding respectively to the sum of the topographic phase (due to inaccuracies in the reference DEM), the deformation phase (due to displacement of the point), the atmospheric delay phase and noise. The technique typically assumes, as is the case in this work, a timelinear dependence for the phase due to displacement (although more complex models can be applied), and uses a statistical characterization of the atmospheric delay to filter it out. In this paper, two distinct PSI algorithms were used: Tele Rilevamento Europa (TRE) PSInSAR, and Altamira Information Stable Point Network (SPN). Both algorithms belong to the PSI family, with a few differences, such as PS selection criteria and specific procedures for filtering atmospheric components.

\subsection{PSI processing}

The PSI technique was used within the GMES-Terrafirma European Project to monitor ground deformation at several European cities (Capes, 2009). In Portugal, GMES-Terrafirma targeted the Lisbon region, with PSI processing conducted in two stages and accounting for about half of the full metropolitan area.

In the first stage, 55 Synthetic Aperture Radar (SAR) images of the Northern metropolitan area acquired by the European Space Agency ERS-1 and ERS-2 satellites between June 1992 and December 2003 were processed with the permanent scatterer interferometry (PSInSAR) algorithm of Ferretti et al. (2001). Tele-rilevamento Europa (TRE) was in charge of the PSI processing. The SAR images were acquired from orbital track 452, in descending pass. This first analysis identified 202108 permanent scatterers (PS) in the study area, with a density of $\sim 250$ points $/ \mathrm{km}^{2}$. All PS had coherences (a measure of the goodness of fit of the model to the observations, ranging from 0 to 1 ) above 0.68 . For each PS, the (mean) annual Line of Sight (LOS) velocity and the displacement temporal series were computed (relative to a reference point in the Restelo area: UTM29N 481794,00E $4284180,55 \mathrm{~N}$, see Fig. 2A). For the entire dataset, the mean LOS velocity in relation to the Restelo reference point ranged at individual PS's from $6.9 \mathrm{~mm} /$ year to $-26.6 \mathrm{~mm} /$ year.

In the second stage, both Northern (Greater Lisbon) and Southern (Setúbal Peninsula) metropolitan areas were chosen for PSI analysis. Altamira Information was in charge of the Permanent Scatterers Interferometry (PSI) processing, which was done with the Stable Point Network software (SPN, Duro et al., 2005). 100 Synthetic Aperture Radar (SAR) scenes, spanning the period July 1992-October 2006, were used from both ERS1/2 and ENVISAT satellites (orbital track 

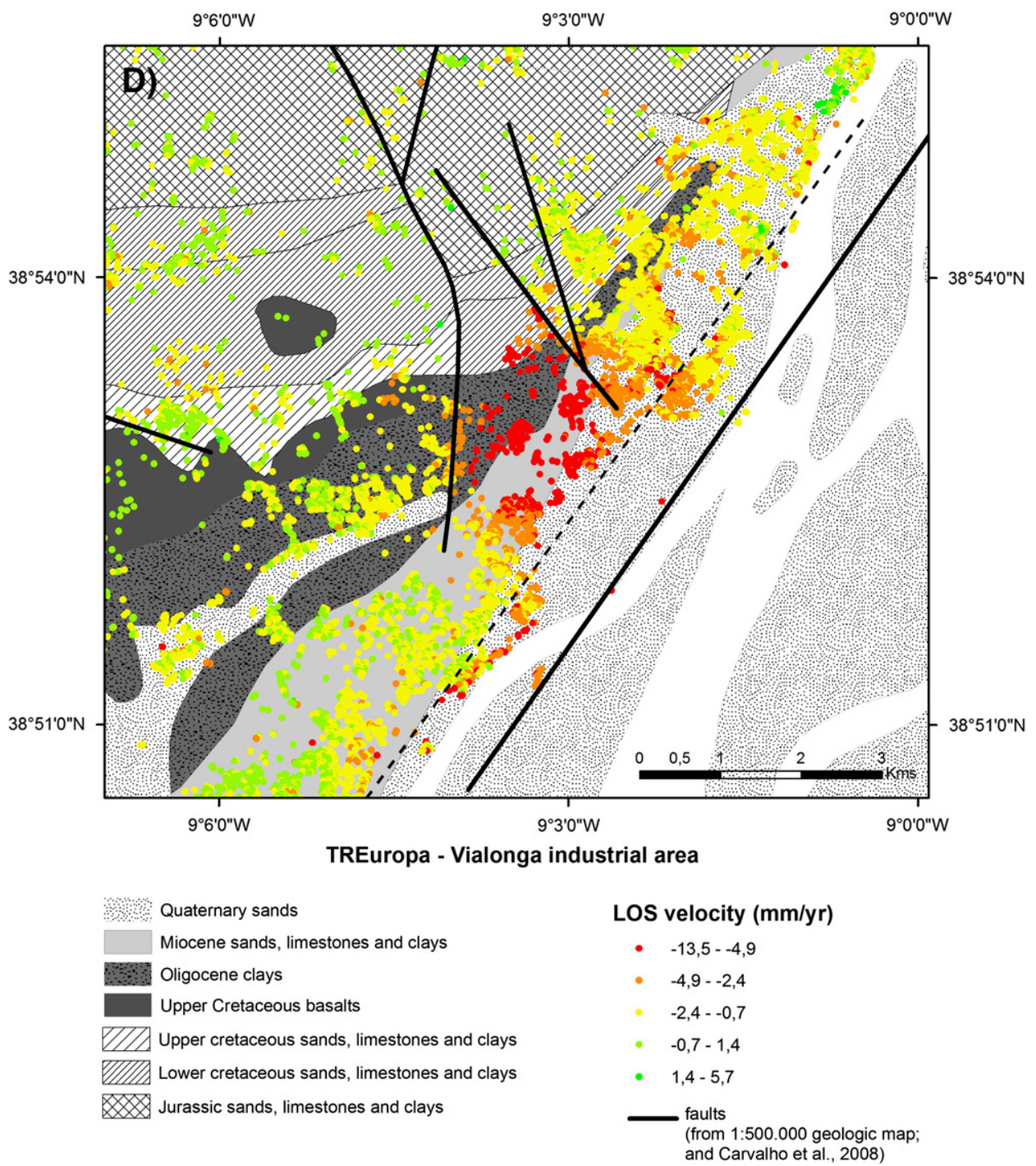

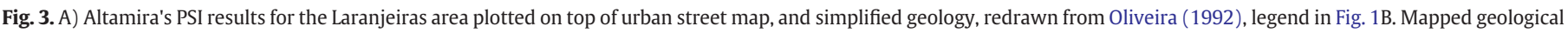

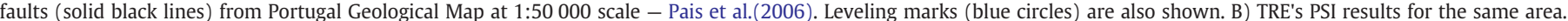

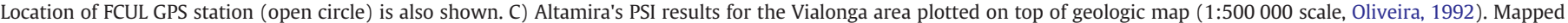

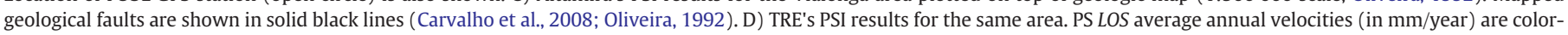

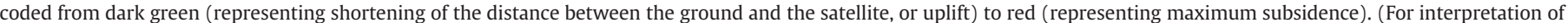
the references to color in this figure legend, the reader is referred to the web version of this article.)

223, descending pass). The time series for ERS and ENVISAT satellites were processed separately and then combined. The SPN software was applied to both southern and northern regions of the metropolitan area of Lisbon (the SPN medium resolution processor was chosen for the latter region). The resulting North and South PSI maps, separated by the Tagus River, are independent from each other, in the sense that the velocities are given in relation to two distinct reference points. The North PSI map depicts 366459 PS, corresponding to a density of $\sim 450$ points $/ \mathrm{km}^{2}$. All PS have coherences above 0.36 (of these, 243989 have coherences higher than 0.5). For each PS, the (mean) annual Line of Sight (LOS) velocity and the displacement temporal series were computed (relative to a reference point coincident with the location of IST1 GPS station: UTM 29N 487957.75E 4287885.22N, see Fig. 2B). For the entire dataset, the average LOS velocity in relation to IST1 reference point ranged at individual PS's from $5.7 \mathrm{~mm} /$ year to $-13.5 \mathrm{~mm} /$ year. The South PSI map depicts 237814 PS, corresponding to a density of $\sim 750$ points $/ \mathrm{km}^{2}$. All PS had coherences above 0.36 (of these, 104006 had coherences higher than 0.5). For each PS, the (mean) annual LOS velocity and the displacement temporal series were computed relative to a reference point in the Setúbal Peninsula, with LOS velocities ranging from $6.1 \mathrm{~mm} /$ year to $-14.2 \mathrm{~mm} /$ year.

Different competing factors contribute for the differences in PS density observed in the TRE and Altamira North datasets (which overlap geographically in the region that will be selected for analysis in the remaining of the paper - see Section 3). The Altamira North procedure used a lower coherence cutoff, and thus discarded fewer candidate PSs. Indeed, if we chose the same cutoff for both result sets (coherence 0.68), Altamira's density lowers to $102 \mathrm{PS} / \mathrm{km}^{2}$, about half of TRE's density ( $250 \mathrm{PS} / \mathrm{km}^{2}$ ). This difference can in turn be explained by the fact that the Altamira's North dataset was processed with medium spatial resolution (via multilooking, or pixel averaging). Finally, although broadly the definition of coherence is the same between the TRE and Altamira algorithms (in the sense that it expresses the goodness of fit of the model to the observations), it is 

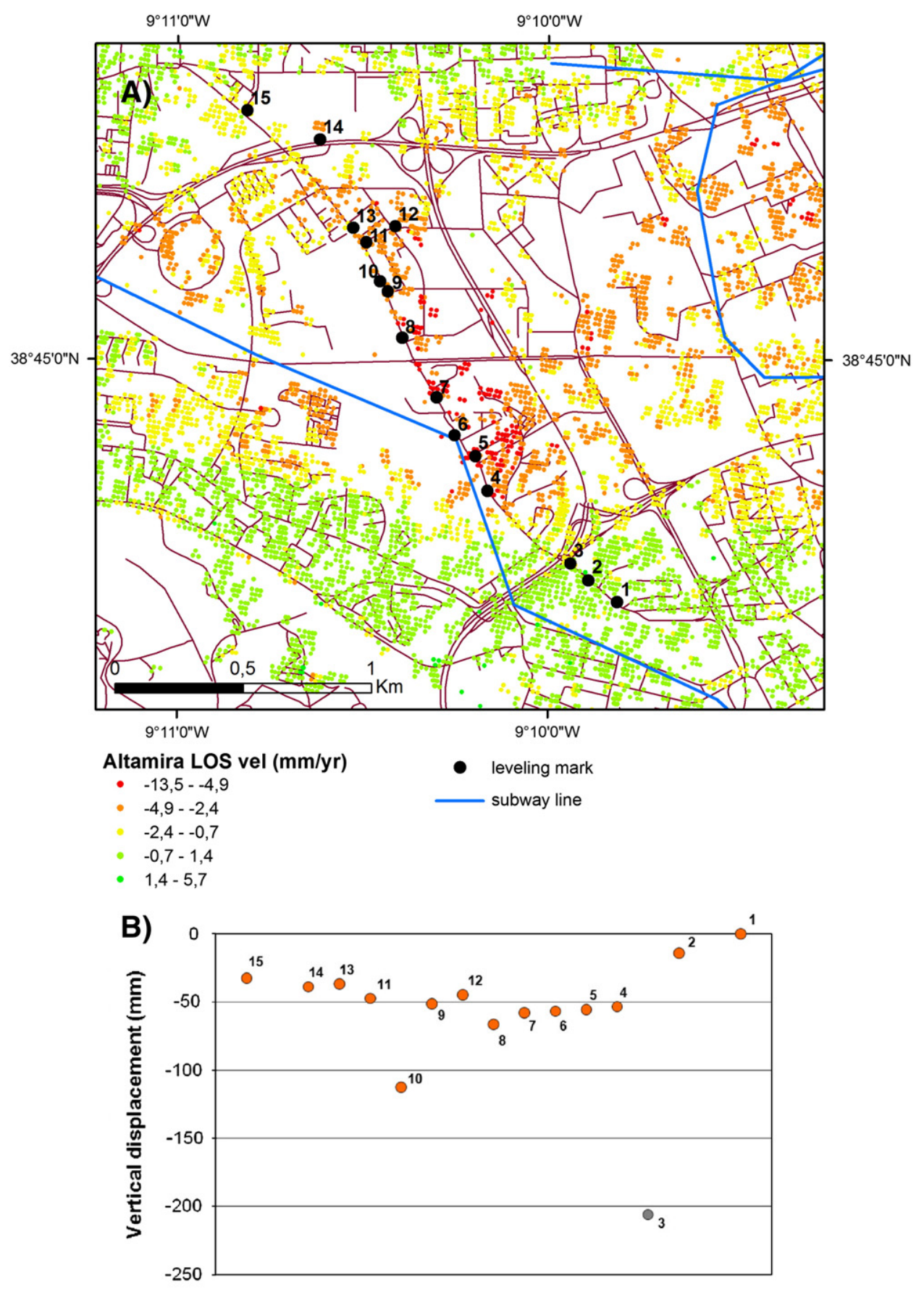

C)

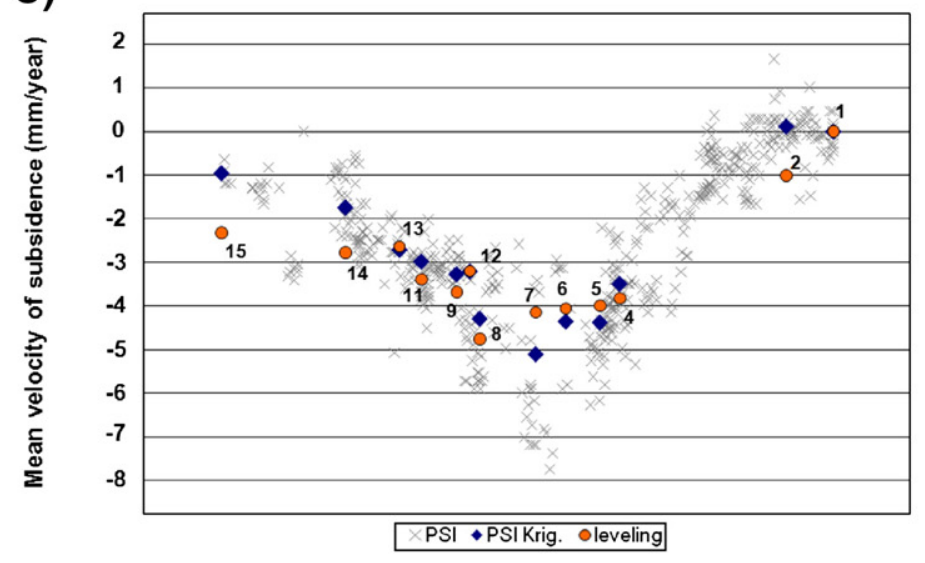




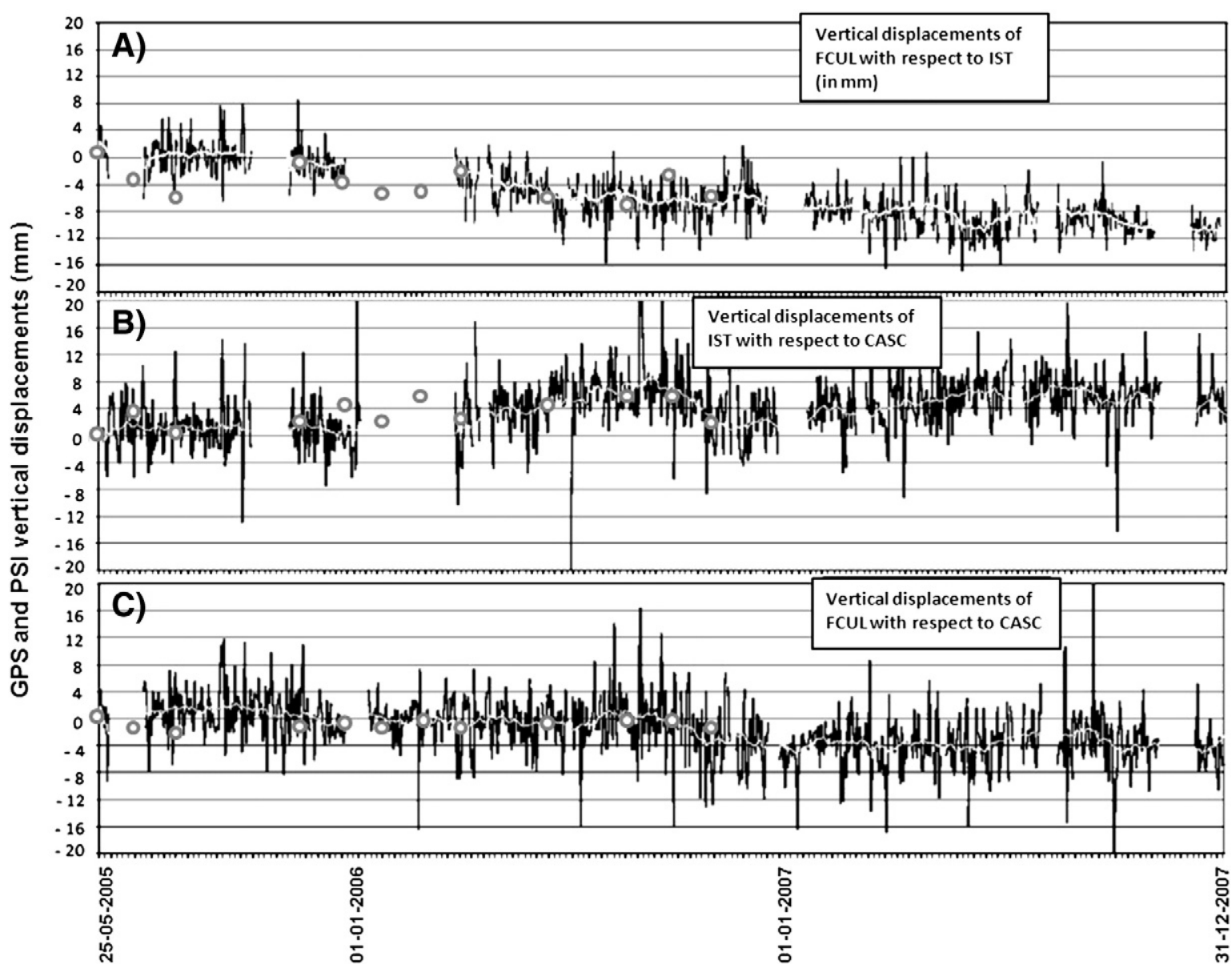

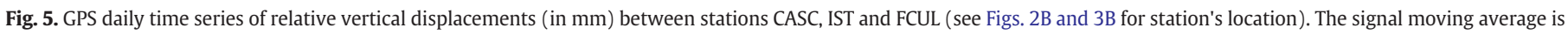

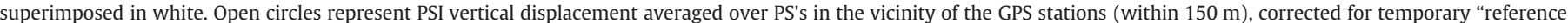

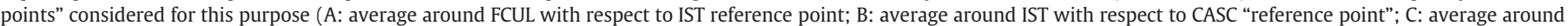
FCUL with respect to CASC "reference point".

unlikely to have two processing chains using different image datasets in different periods to give the same values for the coherence.

\section{PSI results}

As pointed out above, GMES-Terrafirma PSI results integrated both Northern (Greater Lisbon) and Southern (Setúbal Peninsula) metropolitan areas, with PSI processing accomplished in two stages, corresponding to independent PSI results. In this paper we focus on the intersecting area for which we have two overlapping independent PSI mean velocity maps. The two maps are independent in the sense that they were produced by separate processing teams (TRE vs Altamira), separate software (PSInSAR vs SPN), and different SAR images sets acquired from different tracks (452 vs 223) and satellites (ERS1/2 vs ERS1/2 and ENVISAT). The intersecting area is confined to the Northern metropolitan region - its limits include Lisbon city and are presented in Fig. 2. The inspection of this area reveals two welldefined sections (enclosed by rectangles), where most PS points (coded in red/orange/yellow) display velocities corresponding to LOS range lengthening (subsidence), in contrast with the stable surround- ings (coded in green). The rates of subsidence in these two contrasting sections, which dominate both TRE's and Altamira's maps, are the highest retrieved from the PSI processing, and will be the subject of further analysis in this paper. In Figs. 2 and 3 we can compare TRE's and Altamira's PSI overlapping maps, and the coincidence of the boundaries of the two subsiding sectors is striking. These are bordered by sharp velocity gradients, behaving roughly like "blocks" undergoing quasi-uniform subsidence. We will refer to the southwestern section as the "Laranjeiras area", naming it after the Laranjeiras subway station, in the vicinity of which the strongest subsidence was observed. Similarly the northeastern subsiding "block" will be referred to as the "Vialonga area", after the name of the parish were the strongest subsidence was detected.

In Fig. 3 the pattern of subsidence for the Laranjeiras and Vialonga areas is presented in more detail. Fig. 3A,C display Altamira's PSI results, and TRE PSInSAR maps are shown in Fig. 3B,D. The same color code is used for the mean velocity at each point (PS) in both cases. Comparing the two independently processed results, it is clear that both reveal the same subsidence pattern in the two areas under study. In both Laranjeiras and Vialonga areas the subsidence pattern appears

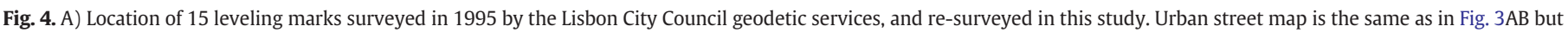

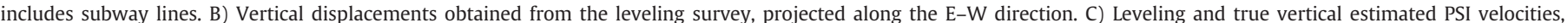

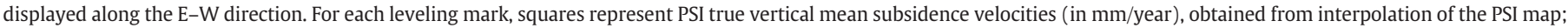

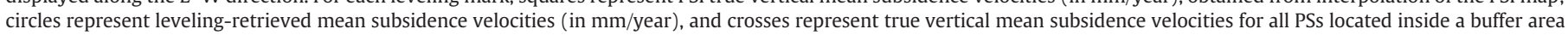
with maximum distance of $100 \mathrm{~m}$ from the leveling line. 
to be partially delimited by mapped (or unidentified?) geologic faults. In the Laranjeiras area, we observe that the southern boundary of the subsidence region is sandwiched between two (close and parallel) mapped geological fault segments: the "Cruz da Pedra" and "Calhariz de Benfica" faults. In the Vialonga area, the subsidence region is partly delimited by two mapped faults that run N-S (to the left in Fig. $3 \mathrm{C}$ ) and NW-SE (to the right in the same figure). In addition, two unmapped lineaments appear to separate stable and subsiding areas: a NNW-SSE linear contrast borders the subsidence in the southwest; and a WNW-ESE lineament delimits the subsidence area to the northeast. These lineaments are not coincident with mapped faults in the current geological maps (either the 1:500 000 scale map in Fig. 3C, D; or the 1:50 000 scale map in Figs. 8 and 9), but could correspond to unidentified fault structures. An important compression fault structure in the Vialonga area which does not yet appear in the geological map is the "Vila Franca de Xira" fault, identified in seismic reflection profiles (Carvalho et al., 2008) and parallel to the shoreline at this location. In Fig. 3C,D the trace proposed by Carvalho et al. (2008) is represented as a solid line, together with an alternative close-by location suggested by us as indicated by the PSI pattern (dashed line).

Quantitatively, the results from the two processing chains (Altamira vs TRE) differ slightly, but one should bear in mind that the time periods of analysis are not the same (1992-2006 vs 1992-2003). In the Laranjeiras area, individual PS Line of Sight (LOS) mean velocity (an approximation of ground subsidence velocity) ranges up to $12 \mathrm{~mm} /$ year in the first case, and up to $11 \mathrm{~mm} /$ year in the later. In the Vialonga area, $14 \mathrm{~mm} /$ year and $15 \mathrm{~mm} /$ year were obtained for the LOS maximum subsidence velocity, for Altamira and TRE respectively. In the Laranjeiras area, two zones are subjected to strongest subsidence: the vicinity of Laranjeiras subway station, with a LOS subsidence rate averaging $5 \mathrm{~mm} / \mathrm{year}$, and part of the Campus of the University of
Lisbon, between the Campo Grande and Cidade Universitária subway stations, with a LOS subsidence rate around $4 \mathrm{~mm} /$ year (Fig. 3A,B). In the Vialonga area, as noticeable in Fig. 3C,D, and already described in this section, a sector of maximum (quasi-uniform) subsidence appears bounded by two mapped faults that run N-S and NW-SE, and by two contrasting lineaments that run NNW-SSE and WNW-ESE toward the river and could correspond to unidentified geologic faults (see also Figs. 8 and 9). The subsidence rate in this sector averages $4 \mathrm{~mm} /$ year (according to Altamira results) or $6 \mathrm{~mm} / \mathrm{year}$ (according to TRE). Both PSI processing results detect a maximum rate of subsidence in the vicinity of the Vialonga brewery, located roughly in the midpoint between the two faults. PS subsidence velocities average $6 \mathrm{~mm} / \mathrm{year}$ (Altamira) or $11 \mathrm{~mm} /$ year (TRE) in the factory's vicinity. In Sections 4 and 5 of this paper, the Laranjeiras area will be the subject of further analysis. Similarly the area of Vialonga will be studied in more detail in Section 6. Both analyses will focus on Altamira PSI results only (which we will refer to simply as "PSI results") since these cover a larger period of time (1992-2006) and use a larger set of (100) SAR images.

\section{Comparison with in situ data}

We resurveyed an old leveling line (Fig. 4A) that crosses the Laranjeiras area subsiding block, passing nearby the Laranjeiras subway station, which is co-located with mark number 6 of the leveling line and whose vicinity undergoes the strongest subsidence. The 15 leveling marks represented in Fig. 4A were surveyed in 1995 by the Lisbon City Council geodetic services. In an attempt to validate the PSI-retrieved subsidence, we re-surveyed the 15 marks in July 2009, using a Leica NA2 automatic level with a micrometer and two 3-meter invar scales. The southernmost mark (mark number 1 in Fig. 4A) was set as the stable reference. The estimated uncertainty of the calculated vertical

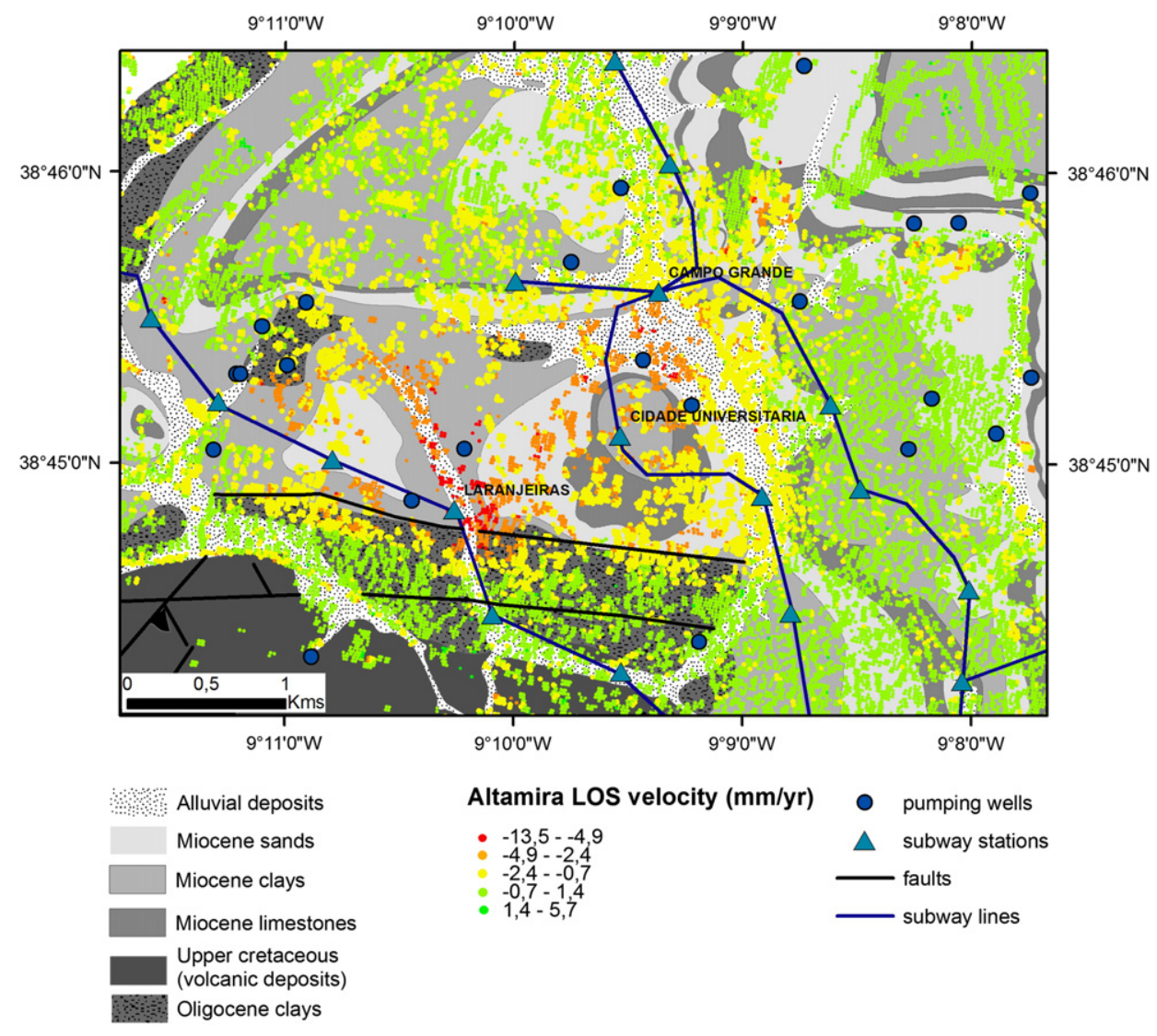

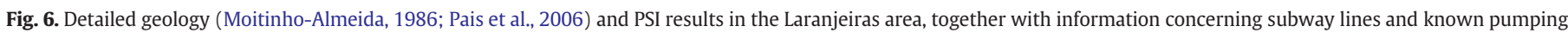
wells in the area (Lisbon City Council database). 


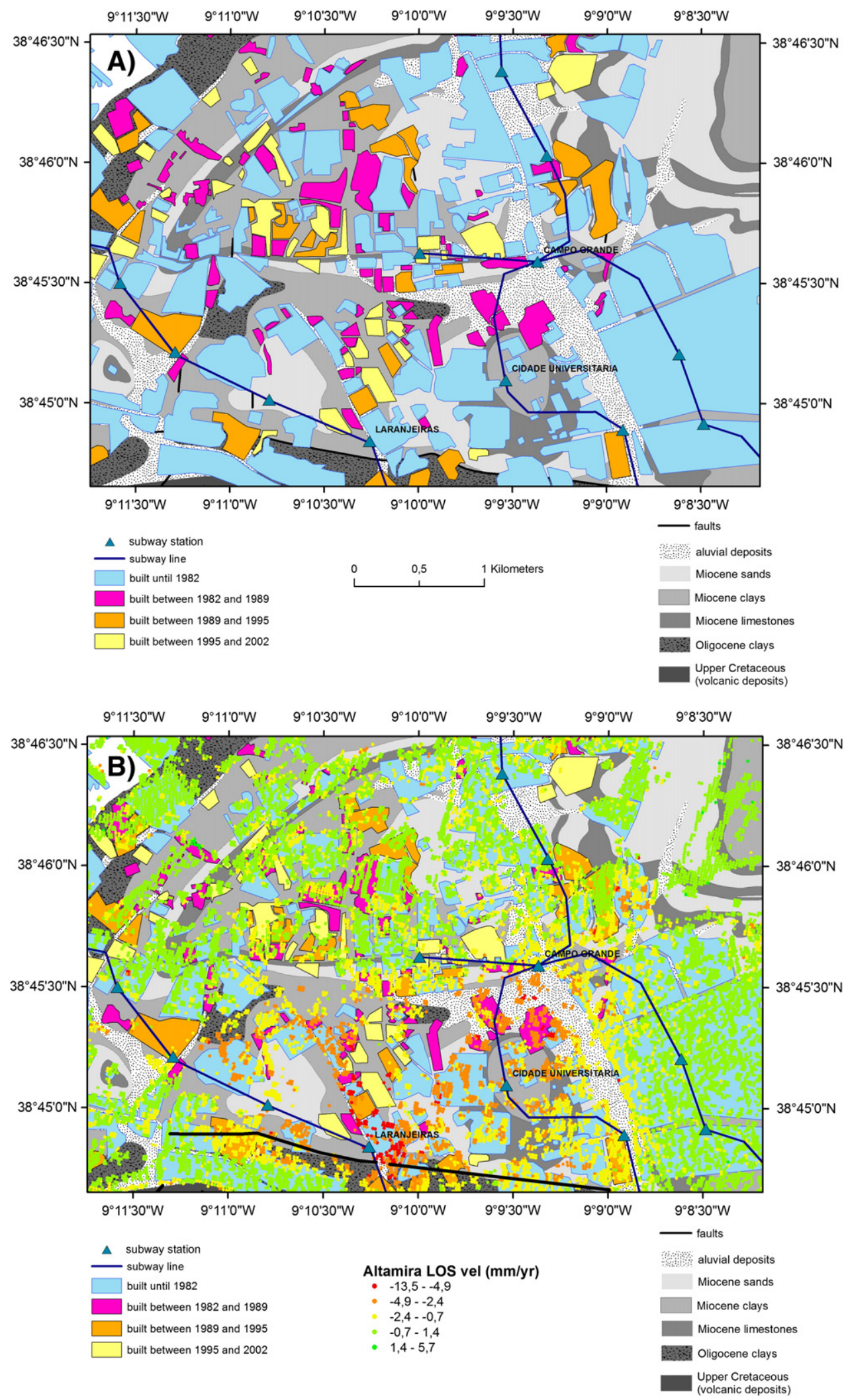

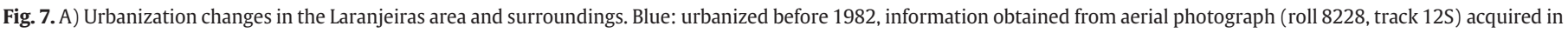

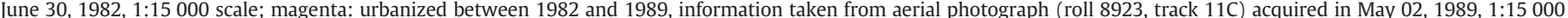

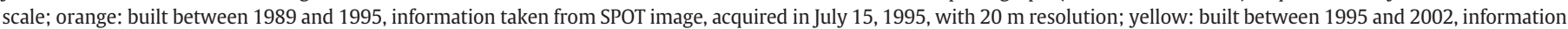

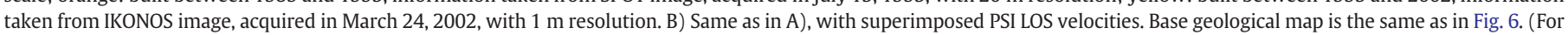
interpretation of the references to color in this figure legend, the reader is referred to the web version of this article.) 


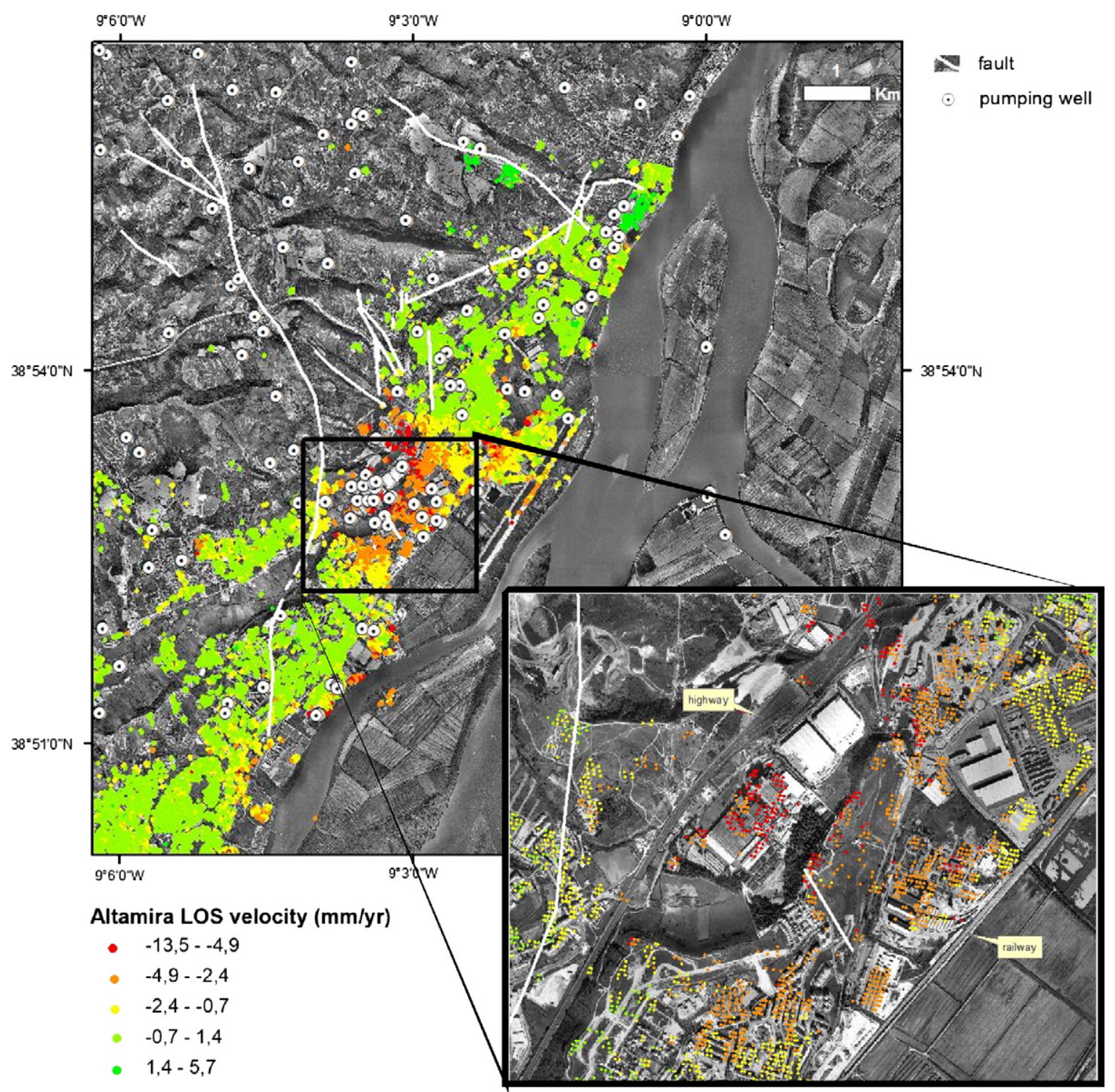

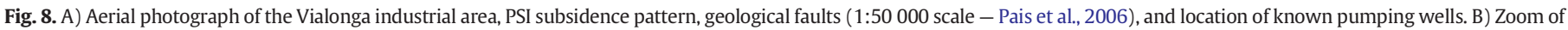
area subjected to highest subsidence, with location of highway and railway lines.

displacements is $2 \mathrm{~mm}$ (Henriques et al., 2009). Fig. 4B presents the calculated vertical displacements for all marks. To facilitate the comparison with the PSI velocity results, the mean annual velocity of subsidence was estimated from the calculated vertical displacements for 13 marks (two marks - 3 and 10 - were discarded as outliers, interpreted as being due to man-made changes in the physical conditions of the leveling marks). Finally, a portion of the PSI mean velocity map, composed of 12560 points, was interpolated with a kriging technique, and the PSI mean annual velocities corresponding to the location of the geodetic marks were retained. These were then projected to true vertical taking in consideration the incidence angle of $23^{\circ}$. In order to further compare the two datasets, we have also selected all PSs located within a distance smaller than $100 \mathrm{~m}$ from the leveling line. Fig. 4C presents the comparison between PSI (both real and interpolated) and leveling mean subsidence velocities (in $\mathrm{mm} / \mathrm{year}$ ) along the leveling profile, projected in the $\mathrm{E}-\mathrm{W}$ direction. The independently computed velocities follow each other closely, and hence provide the validation of the space-borne PSI technique with geodetic in situ data.

From mid 2005 until the end of 2007, we also analyzed Global Positioning System (GPS) data from three permanent stations located in the region: CASC, IST1 (Fig. 2B) and FCUL (Figs. 2B and 3B). FCUL station started operating in mid 2005, and since this is the only station located inside the subsidence area, we chose not to analyze GPS series prior to this date. Daily time series of relative surface displacements between these stations were processed with Bernese 5.0 software (Dach et al., 2007). Ocean loading effects were corrected for each station using the Goddard ocean tide model (Ray, 1999) and using the web-service at http://www.oso.chalmers.se/ loading/ to get the ocean loading coefficients. Fig. 5 presents the relative vertical displacements between stations CASC, IST and FCUL. These results show that the FCUL site, to be found within the Laranjeiras area subsiding block, subsided almost $11 \mathrm{~mm}$ with respect to IST station, located in the stable region, during the $\sim 2.5$ years period processed. This corresponds to a mean annual subsidence velocity of $4.4 \mathrm{~mm} / \mathrm{year}$ and compares favorably with the LOS subsidence rate of $4 \mathrm{~mm} /$ year obtained from the PSI technique in the Campus of the University of Lisbon, where the FCUL station is located, even though this value corresponds to a very different period of time (1992-2006). In Fig. 5A), we can see that the true vertical averaged velocity (represented by open circles) for PSs in the vicinity of FCUL station also follows the GPS trend. At a more regional scale, the GPS and PSI results are also in agreement, since the relative vertical displacement 

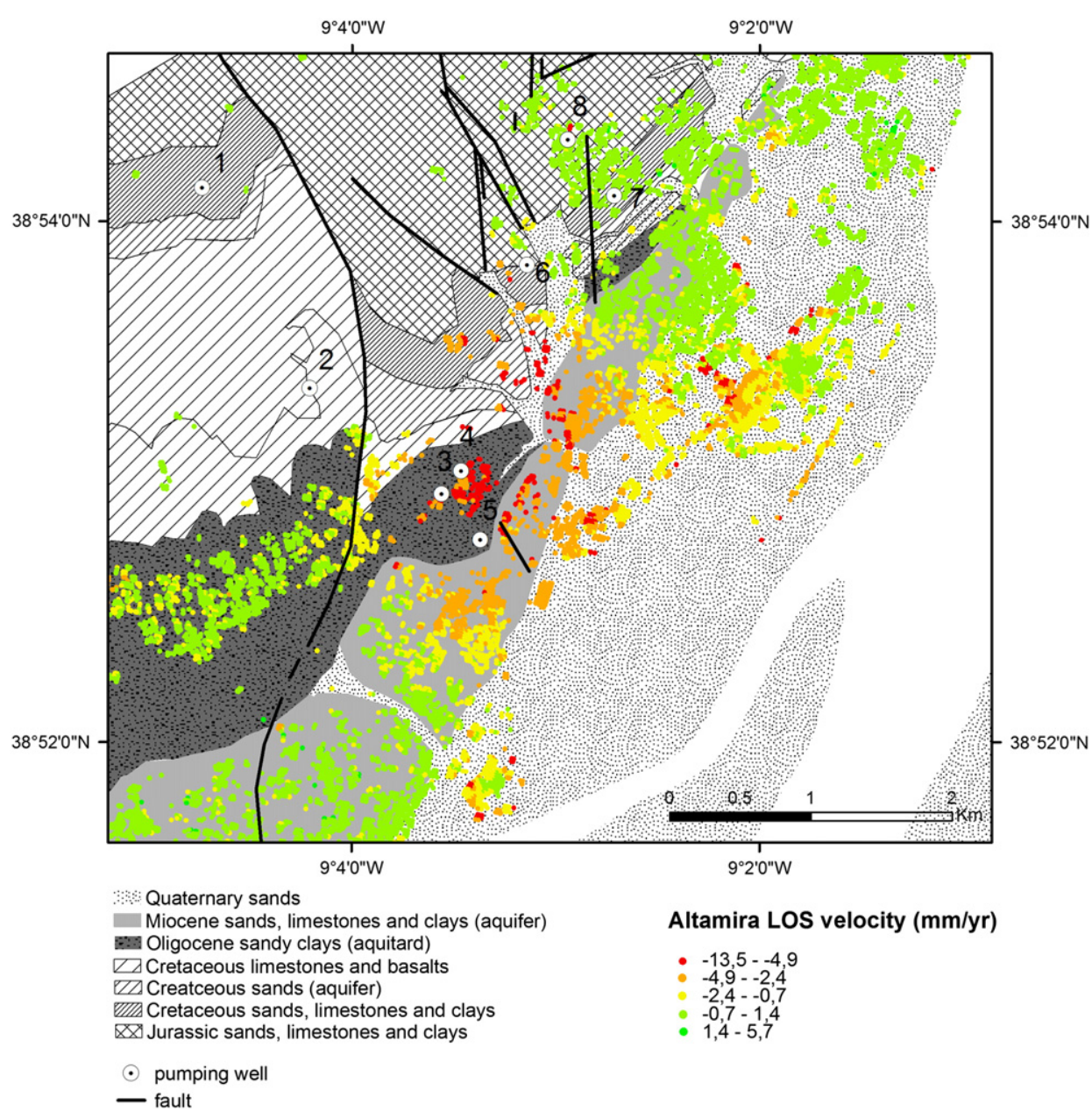

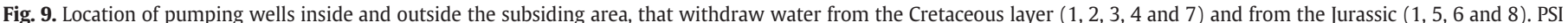
subsidence pattern and geological faults are plotted on top of simplified geology (1:50 000 scale - Pais et al., 2006).

computed between stations IST and CASC is again observed in the PSI true vertical estimated velocity pattern (see Fig. 5BC).

\section{Comparison with surface geology and changes in urbanized area}

Inspection of Fig. 6, where the detailed surface geology is portrayed together with the PSI results, shows that the subsiding "Laranjeiras area" is bordered by mapped outcropping faults (the "Cruz da Pedra" and "Calhariz de Benfica" faults to the South) and by the drainage network trace composed of alluvial material (to the East, Northeast and West). Beneath the Holocene alluvial sands, Mioceneaged clays, limestones, and sands are present and outcrop in the area (Moitinho-Almeida, 1986). A thick clay layer of Eocene-Oligocene age occurs below, outcropping to the south of the "Cruz da Pedra" fault and at some points along the subsiding area northern boundary. The surface geology that characterizes the subsiding Laranjeiras area is similar in the regions that surround it to the North, East and West, which exhibit stable behavior. Hence the correlation with surface geology is unable to explain the subsidence of the Laranjeiras area. Nevertheless, it is clear from Fig. 6 that, within it, the zones subjected to higher rates of subsidence are roughly co-located with alluvialfilled old riverbeds crossing the area (referred to as "alluvial deposits" in Fig. 6 caption). These alluvial soils correspond to the accumulation of fine-grained, compressible deposits that can be susceptible to settle as a consequence of the load imposed by urbanization of the terrain (Ferretti et al., 2004; Stramondo et al., 2008). To test the hypothesis of urbanization load as the cause for the observed subsidence, we analyzed a set of aerial and satellite images acquired over the area. The images used were two aerial photographs (scale 1:15000) acquired in 1982 and 1989; one SPOT image (20 m resolution), acquired in 1995; and one IKONOS image ( $1 \mathrm{~m}$ resolution), acquired in 2002 . The results of this investigation are depicted in Fig. 7, for the Laranjeiras area and surroundings, characterized by similar surface geology. We can see that the area undergoing the highest rate of subsidence (in the vicinity of Laranjeiras subway station, coded in light-blue, in what regards urbanization load) was not subjected to increased urbanization for the last 3 decades. It is also evident from Fig. 7 that the surroundings of the subsiding Laranjeiras area (we stress again, characterized by similar surface geology) were subjected to the same degree of

Table 1

Piezometric levels changes for 4 wells located inside the subsiding area. From Oliveira et al. (2010a).

\begin{tabular}{|c|c|c|c|}
\hline Well & Depth of drilling (m) & Measuring date & Piezometric head (m) \\
\hline \multirow[t]{2}{*}{ AC1 } & 266 & 03-03-1966 & 21 \\
\hline & & 25-06-1993 & -44 \\
\hline \multirow[t]{2}{*}{ AC2 } & 282 & 20-06-1966 & 22.2 \\
\hline & & 25-06-1993 & -37.8 \\
\hline \multirow[t]{3}{*}{ TD1 } & 280 & 22-01-1981 & 9.5 \\
\hline & & 19-07-1983 & -5 \\
\hline & & 25-06-1993 & -35.3 \\
\hline \multirow[t]{2}{*}{ TD2 } & 360 & $10-08-1986$ & -10.7 \\
\hline & & 25-06-1993 & -35 \\
\hline
\end{tabular}


urbanization since the early eighties, without suffering subsidence. It seems clear that surface geology and urbanization alone are unable to explain the phenomena in the Laranjeiras area. In Section 7 other possible causes are tentatively discussed.

\section{Hydrogeology}

Fig. 8 displays an aerial photograph of the Vialonga industrial area, overlaid by PSI subsidence data, depicting also the locations of known pumping wells, obtained from the governmental water authority in the Lisbon region (Oliveira et al., 2009). The area undergoing subsidence is crossed by the main highway and railway that connect Lisbon with the North of the country (zoom in Fig. 8). Several factories, owned by international companies from the beverage, chemical, and agriculture industries, operate in this region. Typically, these industries have high needs for water consumption. Based on data concerning industrial production and processes, Oliveira et al. (2009, 2010a) estimates a minimum value of 9 million $\mathrm{m}^{3}$ for the present annual water needs of the group comprising the three most notable factories in the region. The clusters of subsidence observed in Fig. 8 correlate with the locations of industrial facilities (beverage and chemical factories), transportation services (railway station), or residential areas. In this section we investigate the hypothesis that overexploitation of groundwater, and the resulting compaction of layers in the aquifer system, are the cause of the subsidence observed in the Vialonga area.

The best indicator of overexploitation of groundwater is the historical record of water pore pressure (piezometric head) decline in wells that tap the local aquifer. As far as we know, monitoring of piezometric levels is not implemented in any of the region wells. Oliveira et al. (2009, 2010a, 2010b) were however able to compile a limited number of piezometric time series over the last 45 years for the wells listed in Table 1, all located in the center of the subsiding area. The data show a clear decline of the levels (up to 65 meters in 27 years), which is consistent with the hypothesis of unsustainable exploration of groundwater in this industrial area.

Further information can be extracted from the piezometric levels at wells drilled inside and outside the subsidence area. Fig. 9 depicts the location of eight pumping wells located in the region: wells numbered 2, 3, 4 and 7 withdraw water from Cretaceous layers; wells 5, 6 and 8 tap groundwater from Jurassic layers; and finally well number 1 taps water from Cretaceous and/or Jurassic layers. Tables 2 and 3 compare piezometric levels for wells taping layers of the same geologic age, located inside the subsidence area and to the West of the fault that runs approximately $\mathrm{N}-\mathrm{S}$ (wells $1,2,3$, and 4 ) or inside the subsidence region and to the North of the fault that runs NW-SE and of the lineament with orientation WNW-ESE (wells 3, 4, 5, 6, 7, and 8). These N-S and NW-SE faults, together with the NNW-SSE and WNW-ESE lineaments, separate the subsiding terrain from the stable area. For these wells, the piezometry reveals lower water pressure levels inside the subsiding area, and in most cases large level contrasts across its boundaries. These limited data point to a spatial correlation between the subsidence and

Table 2

Piezometric levels for wells numbered in Fig. 9, located inside the subsiding area and outside to the West.

Adapted from Oliveira et al. (2009).

\begin{tabular}{|c|c|c|c|c|c|}
\hline Well & $\begin{array}{l}\text { Well } \\
\text { position }\end{array}$ & $\begin{array}{l}\text { Depth of } \\
\text { drilling }(\mathrm{m})\end{array}$ & $\begin{array}{l}\text { Measuring } \\
\text { date }\end{array}$ & $\begin{array}{l}\text { Geologic layer } \\
\text { tapped }\end{array}$ & $\begin{array}{l}\text { Piezometric } \\
\text { head }(\mathrm{m})\end{array}$ \\
\hline 1 & $\begin{array}{l}\text { Outside } \\
\text { sub. area }\end{array}$ & 300 & $31-01-2003$ & $\begin{array}{l}\text { Cretaceous } \\
\text { and/or Jurassic }\end{array}$ & 132 \\
\hline 2 & Outside & 103 & 15-07-1995 & Cretaceous & 124.9 \\
\hline 3 & Inside & 266 & 25-06-1993 & Cretaceous & -44 \\
\hline 4 & Inside & 282 & $25-06-1993$ & Cretaceous & -37.8 \\
\hline
\end{tabular}

the water pressure levels, and suggest that faults could be acting as hydraulic barriers in the aquifer system by shielding the aquifer from lateral recharge, either by fault gage waterproofing, or due to fault separation of different permeability materials.

\section{Discussion and conclusion}

The GMES-Terrafirma results presented in this paper correspond, as far as we know, to the first report of urban subsidence in Portugal. Two subsiding urban areas were revealed - one (Laranjeiras) located in the center of Lisbon, another (Vialonga) in an industrial area crossed by Lisbon's main highway and railway lines. Both areas are prone to flooding (Oliveira \& Ramos, 2002; SNIRH), a risk that increases with land subsidence.

The findings reported in this paper expand prior work conducted in the context of project Terrafirma (Fonseca et al., 2006; Heleno et al., 2007, 2008, 2009; Valadão et al., 2005), by offering insight into the cause underlying the subsidence observed. In this process, and as we will discuss bellow, we provide evidence of a link between groundwater exploitation and ground subsidence. The comparison between two independent PSI results, and the comparison with in situ data (leveling and GPS) further contributes to the validation of the PSI technique.

\subsection{Groundwater related subsidence}

The results in the Vialonga area can be compared with numerous case studies of ground subsidence related to groundwater withdrawal described around the world. Examples include Mexico City (CabralCano et al., 2008; López-Quiroz et al., 2009), Venice (Tosi et al., 2002, 2009), Las Vegas (Amelung et al., 1999; Hoffmann et al., 2001), Los Angeles (Bawden et al., 2001), Umbria, Central Italy (Guzzetti et al., 2009), Seattle (Finnegan et al., 2008) and Bologna (Stramondo et al., 2007). These case studies span different degrees of severity of the problem. In Mexico City, for instance, subsidence rates reach up to $400 \mathrm{~mm} / \mathrm{year}$, damaging key urban structures of the city such as domestic and historical buildings, water supply pipes, drainage pipes, gas, electricity and telephone installations (López-Quiroz et al., 2009). In contrast, most subsidence rates over the world are relatively low ( $<10 \mathrm{~mm} /$ year), as is the case described here for metropolitan Lisbon.

In some of the examples referred in the previous paragraph (Cabral-Cano et al., 2008; López-Quiroz et al., 2009; Tosi et al., 2009), the subsidence process is controlled by the non-recoverable compaction of a low permeability and high compressibility aquitard layer, usually composed of clay and silt sediments. This underground compaction is driven by the reduction of water pore pressure inside the aquitard, and is the cause of the surface subsidence. The drop in the aquitard pore pressure is on the other hand caused by reduced pore fluid pressure in adjacent aquifers, when these are subjected to over-exploitation. In Section 6, we were able to provide compelling evidence of over-exploitation of groundwater resources in the Vialonga area (Tables 1, 2 and 3).

The main hydrogeologic systems identified in the Vialonga region are: 1) a deep, Lower Cretaceous, porous aquifer ("Grés de Almargem,

Table 3

Piezometric levels for wells numbered in Fig. 9, located inside the subsiding area and outside to the East.

Adapted from Oliveira et al. (2009).

\begin{tabular}{llllll}
\hline Well & $\begin{array}{l}\text { Well } \\
\text { position }\end{array}$ & $\begin{array}{l}\text { Depth of } \\
\text { drilling }(\mathrm{m})\end{array}$ & $\begin{array}{l}\text { Measuring } \\
\text { date }\end{array}$ & $\begin{array}{l}\text { Geologic layer } \\
\text { tapped }\end{array}$ & $\begin{array}{l}\text { Piezometric } \\
\text { head }(\mathrm{m})\end{array}$ \\
\hline 5 & Inside sub. area & 670 & 2001 & Jurassic & -98 \\
6 & Outside & 150 & 2001 & Jurassic & -5 \\
8 & Outside & 150 & 2004 & Jurassic & 60 \\
3 & Inside & 266 & $25-06-1993$ & Cretaceous & -44 \\
4 & Inside & 282 & $25-06-1993$ & Cretaceous & -37.8 \\
7 & Outside & 72 & $11-06-1996$ & Cretaceous & -20 \\
\hline
\end{tabular}


Aptiano-Albiano", Zbyszewski, 1964), about $180 \mathrm{~m}$ thick (Oliveira et al., 2009); 2) an intermediate, Oligocene aged, clay-rich aquitard ("Complexo de Benfica", Zbyszewski, 1964), about $150 \mathrm{~m}$ thick (Oliveira et al., 2009); and 3) a multi-layered sand-clay-limestone Miocene aquifer, about $150 \mathrm{~m}$ thick (Oliveira et al., 2009), outcropping closer to the river. Pumping wells in the area are known to extract water from aquifers (1) and (3). Since the Oligocene aquitard (2) is the unit with highest clay content, and hence the most compressible, we consider it as the most probable unit to control the subsidence. This hypothesis is supported by the work of López-Quiroz et al. (2009) and Cabral-Cano et al. (2008) in Mexico City, or Tosi et al. (2009) in Venice. The surface subsidence detected by the PSI technique is hence most probably caused by compaction of the clayrich Oligocene aquitard (2), led by over-exploitation of the adjacent aquifers (1) and (3). We cannot however rule out that some subsidence occurs due to aquifer compaction, although probably with a comparative smaller importance since both the Miocene aquifer or the deep Cretaceous aquifer are characterized by a lower proportion of clay (Oliveira et al., submitted for publication).

The Oligocene aquitard layer (2) is also present in the Laranjeiras area, immediately bellow the multi-layered sand-clay-limestone Miocene aquifer (3), and in Fig. 5B we can see that pumping wells are exploring the groundwater resources in the area. Further work is needed to monitor piezometric levels in the Laranjeiras area, in order to diagnose the possibility of over-exploitation of groundwater. Work on groundwater flow and subsidence modeling in the Vialonga area will be published elsewhere (Oliveira et al., submitted for publication).

\subsection{Relation with active tectonics}

InSAR and PS Interferometry have been used for measuring regional interseismic strain accumulation across tectonic faults (Motagh et al., 2007; Wright et al., 2001) or local shallow aseismic fault creep across fault segments (Funning et al., 2007). The distinction between fault creep and groundwater related subsidence is difficult because faults can locally control groundwater movement, so that in both cases the result is sharp deformation gradients coinciding with the locations of known (or previously unknown) faults, as seems to be the case in Laranjeiras and Vialonga. In the Vialonga case, the piezometric head drop in local wells supports the groundwater hypothesis. In the Laranjeiras area, the faults that border the subsidence pattern in the South are old structures (possibly Miocene-aged, according to Pais et al., 2006), suggesting that subsidence could be controlled by the different hydrogeological characteristics of the materials separated by these structures. However further work is needed before active tectonics can be excluded as cause of the subsidence.

\subsection{PSI validation}

Our investigation was not oriented toward a systematic and accurate PSI validation - an exercise that readers can find for example in Crosetto et al. (2008) and Raucoules et al. (2009). Nevertheless, in our work we were able to independently confirm the PSI results, in two ways. First, by comparing autonomous PSI results processed for the same geographical areas, which coincided qualitatively, and quantitatively differed only slightly (Section 3). Secondly, by comparing PSI and in situ derived mean subsidence velocities (with leveling and continuous GPS), whose close match provided further ground validation of the space-borne PSI technique (Section 4), expanding previous validation work by Fonseca et al. (2006).

\section{Acknowledgments}

This work was supported by the European Space Agency (GMESTerrafirma, ESRIN Contract 19366/05/I-EC), and by the Fundação para a Ciência e a Tecnologia, Lisbon (Project SUBSIn, FCT contract PTDC/
CTE-GEX/65261/2006). We are grateful to the Lisbon City Council for providing us with diverse geographic information, including leveling marks and well locations in the Laranjeiras area. We show appreciation to "Comissão de Coordenação e Desenvolvimento Regional de Lisboa e Vale do Tejo" for providing us with well data from the Vialonga area. Aerial photographs used were kindly provided by Instituto Geográfico Português. Discussions concerning the hydrogeology and structural geology of the area under study with Malva Mancuso, Jaime Cabral, Glenda Besana-Ostman and Albino Medeiros were extremely useful. We also acknowledge fruitful discussions with Manuel Oliveira, Cláudia Pinto, João Carvalho, Jorge de Sousa and José Vicente, which were valuable at various stages of the work.

\section{References}

Amelung, F., Galloway, D., Bell, J., Zebker, H., \& Laczniack, R. (1999). Sensing the ups and downs of Las Vegas: InSAR reveals structural control of land subsidence and aquifer-system deformation. Geology, 27(6), 483-486.

Bawden, G., Thatcher, W., Stein, R., Hudnut, K., \& Peltzer, G. (2001). Tectonic contraction across Los Angeles after removal of groundwater pumping effects. Nature, 412, 812-815.

Bossard, M., Feranec, J., \& Otahel, J. (2000). CORINE land cover technical guide Addendum 2000. Technical report no 40 . Copenhagen (EEA). http: //terrestrial.eionet.eu.int

Burgmann, R., Rosen, P. A., \& Fielding, E. J. (2000). Synthetic aperture radar interferometry to measure Earth's surface topography and its deformation. Annual Review of Earth and Planetary Sciences, 28, 169-209.

Cabral-Cano, E, Dixon, T. Miralles-Wilhelm, F, Díaz-Molina, O. Sánchez-Zamora, O \& Carande, R. (2008). Space geodetic imaging of rapid ground subsidence in Mexico City. Geological Society of America Bulletin, 120, 1556-1566.

Capes, R. (2009). The Terrafirma Atlas. GMES-Terrafirma, ESRIN Contract 19366/05/IEC, available at. http://www.terrafirma.eu.com/documents.htm last accessed May 16,2010

Carvalho, J., Cabral, J., Gonçalves, R., Torresa, L., \& Mendes-Victor, L. (2006). Geophysical methods applied to fault characterization and earthquake potential assessment in the Lower Tagus Valley, Portugal. Tectonophysics, 418(3-4), 277-297.

Carvalho, J., Matias, L., Torresa, L., Manupella, G., Pereira, R., \& Mendes-Victor, L. (2005). The structural and sedimentary evolution of the Arruda and Lower Tagus subbasins, Portugal. Marine and Petroleum Geology, 22, 427-453.

Carvalho, J., Rabeh, T., Cabral, J., Carrilho, F., \& Miranda, J. (2008). Geophysical characterization of the Ota-Vila Franca de Xira-Lisbon-Sesimbra fault zone, Portugal. Geophysical Journal International, 174, 567-584.

Crosetto, M., Monserrat, O., Adam, N., Parizzi, A., Bremmer, C., Dortland, S., et al. (2008). Validation of existing processing chains in Terrafirma stage 2. Final report. GMES TERRAFIRMA ESRIN/Contract no. 19366/05/I-E.

Dach, R., Hugentobler, U., Fridez, P., \& Meindl, M. (2007). Bernese GPS software version 5.0. : Astronomical Institute, University of Berne.

Delacourt, C., Briole, P., \& Achache, J. (1998). Tropospheric corrections of SAR interferograms with strong topography. Application to Etna. Geophysical Research Letters, 25 (15), 2849-2852. doi:10.1029/98GL02112.

Duro, J., Inglada, J., Closa, J., Adam, N., \& Arnaud, A. (2005, December 1-5). Highresolution differential interferometry using time series of ERS and ENVISAT SAR data. FRINGE 2003 Frascati (Italy).

Fernandez, P., Irigaray, C., Jimenez, J., El-Hamdouni, R., Crosetto, M., Monserrat, O., et al. (2009). First delimitation of areas affected by ground deformations in the Guadalfeo River Valley and Granada metropolitan area (Spain) using the DInSAR technique. Engineering Geology, 105, 84-101.

Ferretti, A., Novali, F., Burgmann, R., Hilley, G., \& Prati, C. (2004). InSAR permanent scatterer analysis reveals ups and downs in San Francisco Bay area. Eos, Transactions American Geophysical Union, 85(34), 317.

Ferretti, A., Prati, C., \& Rocca, F. (2000). Non-linear subsidence rate estimation using permanent scatterers in differential SAR interferometry. IEEE Transactions on Geoscience and Remote Sensing, 38(5), 2202-2212.

Ferretti, A., Prati, A., \& Rocca, F. (2001). Permanent scatterers in SAR. IEEE Transactions on Geoscience and Remote Sensing, 39(1), 8-20.

Finnegan, N., Pritchard, M., Lohman, R., \& Lundgren, P. (2008). Constraints on surface deformation in the Seattle, WA, urban corridor from satellite radar interferometry time-series analysis. Geophysical Journal International, 174, 29-41.

Fonseca, J. F., Ferretti, A., Heleno, S. I., \& Falcão, A. P. (2006). Can inter-seismic/preseismic deformation be monitored with PSInSAR? An example from the Lower Tagus Valley, Portugal. American Geophysical Union Fall Meeting 2006, San Francisco, Califórnia November 2006 (poster).

Funning, G. J., Burgmann, R., Ferretti, A., Novali, F., \& Fumagalli, A. (2007). Creep on the Rodgers Creek fault, northern San Francisco Bay area from a 10 year PS-InSAR dataset. Geophysical Research Letters, 34, L19306. doi:10.1029/2007GL030836.

Gabriel, A. K., Goldstein, R. M., \& Zebker, H. A. (1989). Mapping small changes over large areas: Differential radar interferometry. Journal of Geophysical Research, 94, 9183-9191.

Guzzetti, F., Manunta, M., Ardizzone, F., Pepe, A., Cardinali, M., Zeni, G., et al. (2009). Analysis of ground deformation detected using the SBAS-DInSAR technique in Umbria, Central Italy. Pure and Applied Geophysics, 166(8-9), 1425-1459. 
Hanssen, R. (2001). Radar interferometry, data interpretation and error analysis. : Kluwer Academic Publishers.

Heleno, S. I. N., \& Fonseca, J. F. B. D. (2007, November 5). Further investigation on the use of PSInSAR data to characterize the active tectonics of the Lower Tagus Valley. GMES TERRAFIRMA Workshop 4. Frascati, Italy: ESRIN.

Heleno, S. I. N., Loureiro, A., Fonseca, J., Matos, J., Carvalho, J., Cooksley, G., et al. (2008, May 12-15). Detection of ground motion in the Lisbon region with persistent scatterer interferometry (PSI). Measuring the Changes. Lisbon: LNEC.

Heleno, S. I. N., Oliveira, L. G. S., Vicente, J., Falcão, A., Carvalho, J., Lobo-Ferreira, J., et al. (2009, March 25-26). PSI reveals deformation associated with groundwater withdrawal in the Lower Tagus Valley tectonic setting. GMES Terrafirma 5th Workshop. Frascati, Italy: ESRIN.

Henriques, M. J., Lima, J. N., Falcão, A. P., \& Heleno, S. I. N. (2009, October 12-13). Validação com nivelamento geométrico da subsidência detectada no centro de Lisboa com psinsar. $2^{\circ}$ Encontro Nacional de Geodesia Aplicada. : LNEC.

Hoffmann, J., Zebker, H., Galloway, D., \& Amelung, F. (2001). Seasonal subsidence and rebound in Las Vegas Valley, Nevada, observed by synthetic aperture radar interferometry. Water Resources Research, 37(6), 1551-1566.

Hooper, A., Zebker, H., Segall, P., \& Kampes, B. (2004). A new method for measuring deformation on volcanoes and other natural terrains using InSAR persistent scatterers. Geophysical Research Letters, 31, L23611.

Kampes, B. (2006). Radar interferometry: Persistent scatterer technique. : Springer.

López-Quiroz, P., Doin, M., Tupin, F., Briole, P., \& Nicolas, J. (2009). Time series analysis of Mexico City subsidence constrained by radar interferometry. Journal of Applied Geophysics, 69(1), 1-15.

Massonnet, D., \& Feigl, K. (1998). Radar interferometry and its application to changes in the Earth's surface. Reviews of Geophysics, 36, 441-500.

Moitinho-Almeida, F. (1986). Carta geológica do Concelho de Lisboa. Escala 1:10000. Direccão Geral de Geologia e Minas. Serviços Geológicos de Portugal, Lisboa.

Motagh, M., Hoffmann, J., Kampes, B., Baes, M., \& Zschau, J. (2007). Strain accumulation across the Gazikoy-Saros segment of the North Anatolian Fault inferred from persistent scatterer interferometry and GPS measurements. Earth and Planetary Science Letters, 255(3-4), 432-444.

Oliveira, T. (1992). Carta Geológica de Portugal. Escala 1:500.000. Serviços Geológicos de Portugal.

Oliveira, C. S. (2008). Lisbon earthquake scenarios: A review on uncertainties, from earthquake source to vulnerability modeling. Soil Dynamics and Earthquake Engineering, 28(10-11), 890-913.

Oliveira, L. G. S., Lobo-Ferreira, J. P., Cabral, J., Medeiros, A., \& Heleno, S. I. N. (2010a). Subsidência de terrenos por extracção de água subterrânea. Aplicação ao caso de estudo da zona industrial de Vialonga. $10^{\circ}$ Congresso da Água, 21-24 March, Algarve, Portugal.

Oliveira, L. G. S., Lobo-Ferreira, J. P. C., \& Heleno, S. I. N. (2009). Subsin - Utilização Do INSAR Na Deteç̧ão E Caracterização De Subsidência E Deslizamentos Do Solo Na Região De Lisboa: Componente Águas Subterrâneas - Primeiro relatório de progresso referente às bases teóricas e caracterização dos casos em estudo. Relatório 236/2009 - NAS. Lisboa: Laboratório Nacional de Engenharia Civil 82 pp.

Oliveira, L. G. S., Lobo-Ferreira, J.. P. C., \& Heleno, S. I. N. (2010b). Subsin - Utilização Do INSAR Na Detecção E Caracterização De Subsidência E Deslizamentos Do Solo Na Região De Lisboa: Componente Águas Subterrâneas - Segundo relatório de progresso referente à análise DPSIR (Driving Forces-Pressures-State-Impact-Responses) e à modelação de subsidência do caso de estudo em Vialonga. Relatório 6/2010-NAS. Lisboa: Laboratório Nacional de Engenharia Civil 57 pp.
Oliveira, P. E., \& Ramos, C. (2002). Inundaccões na cidade de Lisboa durante o Século XX e seus factores agravantes. Finisterra, XXXVII(74), 33-54.

Oliveira, L. S. G., Lobo-Ferreira, J. P., Cabral, J., Medeiros, A., Cooksley, G., Heleno, S. (submitted for publication). Submitted to Environmental Earth Sciences. Land subsidence due to groundwater overexploitation: The industrial zone of Vialonga (Portugal).

Oliver, C., \& Quegan, S. (2004). Understanding synthetic aperture radar images. Boston.

Pais, J., Moniz, C., Cabral, J., Cardoso, J., Lagoinha, P., Machado, S., et al. (2006). Carta Geológica de Portugal (e notícia explicativa) na escala 1:50000 - folha 34-D, Lisboa ( $2^{\mathrm{a}}$ edição), LNEG, Lisboa.

Raucoules, D., Bourgine, B., de Michele, M., Le Cozannet, G., Closset, L., Bremmer, C., et al (2009). Validation and intercomparison of Persistent Scatterers Interferometry: PSIC4 project results. Journal of Applied Geophysics, 68, 335-347.

Ray, R. D. (1999). A global ocean tide model from Topex/Poseidon altimetry. NASA Tech. Memo. 209478. Greenbelt: Goddard Space Flight Center 58 pp.

Silva, E. A., \& Clarke, K. C. (2002). Calibration of the SLEUTH urban growth model for Lisbon and Porto, Portugal. Computers, Environment and Urban Systems, 26, 525-552.

SNIRH (H). Sistema Nacional de Informação de Recursos Hídricos. (. http://snirh.pt/ last accessed in March 22 2011)

Stramondo, S., Bozzano, F., Marra, F., Wegmuller, U., Cinti, F. R., Moro, M., et al. (2008) Subsidence induced by urbanisation in the city of Rome detected by advanced InSAR technique and geotechnical investigations. Remote Sensing of Environment, 112, 3160-3172.

Stramondo, S., Saroli, M., Tolomei, C., Moro, M., Doumaz, F., Pesci, A., et al. (2007) Surface movements in Bologna (Po Plain - Italy) detected by multitemporal DInSAR. Remote Sensing of Environment, 110, 304-316.

Tosi, L., Carbognin, L., Teatini, P., Strozzi, T., \& Wegmuller, U. (2002). Evidence of the present relative land stability of Venice, Italy, from land, sea, and space observations. Geophysical Research Letters, 29(1562) 4 pp.

Tosi, L., Teatini, P., Carbognin, L., \& Brancolini, G. (2009). Using high-resolution data to reveal depth-dependent mechanisms that drive land subsidence: The Venice coast, Italy. Tectonophysics, 474(1-2), 271-284.

Valadão, G., Matos, J. L., Oliveira, C. S., Fonseca, J. F., Santos, M., \& Novali, F. (2005). Subsidências para a região de Lisboa por PSInSAR: análise preliminary de resultados. Proc. Conf. Nacional de Cartografia e Geodesia, 1. (pp. 378-383) Lisboa, Portugal.

Vilanova, S. P., \& Fonseca, J. F. (2004). Seismic hazard impact of the Lower Tagus Valley Fault Zone (SW Iberia). Journal of Seismology, 8, 331-345.

Vilanova, S. P., Nunes, C., \& Fonseca, J. F. (2003). Lisbon 1755: A case of triggered onshore rupture? Bulletin of the Seismological Society of America, 93(5), 2056-2068.

Vis, G., Kasse, C., \& Vandenberghe, J. (2008). Late Pleistocene and Holocene palaeogeography of the Lower Tagus Valley (Portugal): Effects of relative sea level, valley morphology and sediment supply. Quaternary Science Reviews, 27, 1682-1709.

Wright, T., Parsons, B., \& Fielding, E. (2001). Measurement of interseismic strain accumulation across the North Anatolian Fault by satellite radar interferometry. Geophysical Research Letters, 28(10), 2117-2120.

www.terrafirma.eu.com GMES-Terrafirma, last accessed May 162010

Zbyszewski, G. (1964). Carta geológica dos arredores de Lisboa. Escala de 1/50000 Notícia Explicativa da folha 2 (Loures). Serviços Geológicos de Portugal, 86 pp. 